Check for updates

Cite this: RSC Adv., 2019, 9, 18124

Received 12th April 2019

Accepted 2nd June 2019

DOI: $10.1039 / c 9 r a 02765 c$

rsc.li/rsc-advances

\section{Mimicking growth factors: role of small molecule scaffold additives in promoting tissue regeneration and repair}

\begin{abstract}
Nowsheen Goonoo and Archana Bhaw-Luximon (DD *
The primary aim of tissue engineering scaffolds is to mimic the in vivo environment and promote tissue growth. In this quest, a number of strategies have been developed such as enhancing cell-material interactions through modulation of scaffold physico-chemical parameters. However, more is required for scaffolds to relate to the cell natural environment. Growth factors (GFs) secreted by cells and extracellular matrix (ECM) are involved in both normal repair and abnormal remodeling. The direct use of GFs on their own or when incorporated within scaffolds represent a number of challenges such as release rate, stability and shelf-life. Small molecules have been proposed as promising alternatives to GFs as they are able to minimize or overcome many shortcomings of GFs, in particular immune response and instability. Despite the promise of small molecules in various TE applications, their direct use is limited by nonspecific adverse effects on non-target tissues and organs. Hence, they have been incorporated within scaffolds to localize their actions and control their release to target sites. However, scanty rationale is available which links the chemical structure of these molecules with their mode of action. We herewith review various small molecules either when used on their own or when incorporated within polymeric carriers/scaffolds for bone, cartilage, neural, adipose and skin tissue regeneration.
\end{abstract}

\section{Introduction}

During the tissue repair process, the ability to control and guide cellular differentiation towards a given lineage and promotion of tissue growth are crucial for optimal tissue healing. In this regard, several techniques have been investigated including the use of physical ${ }^{1,2}$ and biochemical cues. ${ }^{3-5}$ The physical and chemical natures of scaffolds may significantly impact on cellular differentiation., ${ }^{1,6}$ Scaffold characteristics such as mechanical stiffness, ${ }^{7,8}$ surface topography ${ }^{2}$ and chemical functional groups ${ }^{3}$ can be varied to give rise to specific tissue lineages. A number of reviews have discussed these parameters in details. ${ }^{9-11}$ For instance, Hammerick et al. showed that stiff materials lead to osteogenic differentiation while elastic environments were conducive for myocyte (muscle cell) and neural differentiation. ${ }^{12}$ Amino and hydroxyl chemical functionalities on biomaterial surfaces favor osteogenesis ${ }^{3,7}$ while acrylate groups maintain the multi-potency of progenitors. ${ }^{13}$

Among biochemical strategies, the use of growth factors (GFs) has received considerable clinical interest. GFs can upregulate or down-regulate cellular activities (adhesion, proliferation and differentiation) by binding to cell surface receptors

Biomaterials, Drug Delivery and Nanotechnology (BDDN) Unit, Centre for Biomedical and Biomaterials Research, University of Mauritius, Réduit, Mauritius. E-mail: abluximon@gmail.com; a.luximon@uom.ac.mu which in turn activates signaling pathways (Scheme 1). In the mathematical game theory of cells, a fraction of cells (producers) secrete GFs. ${ }^{14}$ The benefit of the GFs produced is not restricted to the producer cells, as it can be exploited by all other cells within the diffusion range of the GF, including nonproducer cells. GFs have been shown to be present during the development and healing of various tissues and hence, their incorporation and controlled release from scaffolds is a popular technique considered to accelerate tissue repair. However, despite successful in vitro results, only few studies have proceeded to clinical trials. Additional concerns of GFs include their appropriate dosage, low half-life, instability, high cost, and possible negative long term side effects. ${ }^{15}$

Recently, small molecules ( $<1000 \mathrm{Da}$ ) were found to be able to activate particular signaling pathways that may for example lead to osteoblastic growth and differentiation. ${ }^{16}$ Unlike GFs, these small molecules are easier to manufacture or are available from bioresources, are less costly, and less prone to denaturation. However, the dosage and route of administration remains a critical factor in achieving the highest efficacy and to avoid toxicity with these small molecules..$^{15}$ Resolving the multiple actions of small molecules on signaling pathways is also an area where more research has to be performed as they lack specificity. ${ }^{16}$

In this review, we will discuss the role of some common GFs in tissue regeneration, the impact of small molecules in $\mathrm{TE}$ 


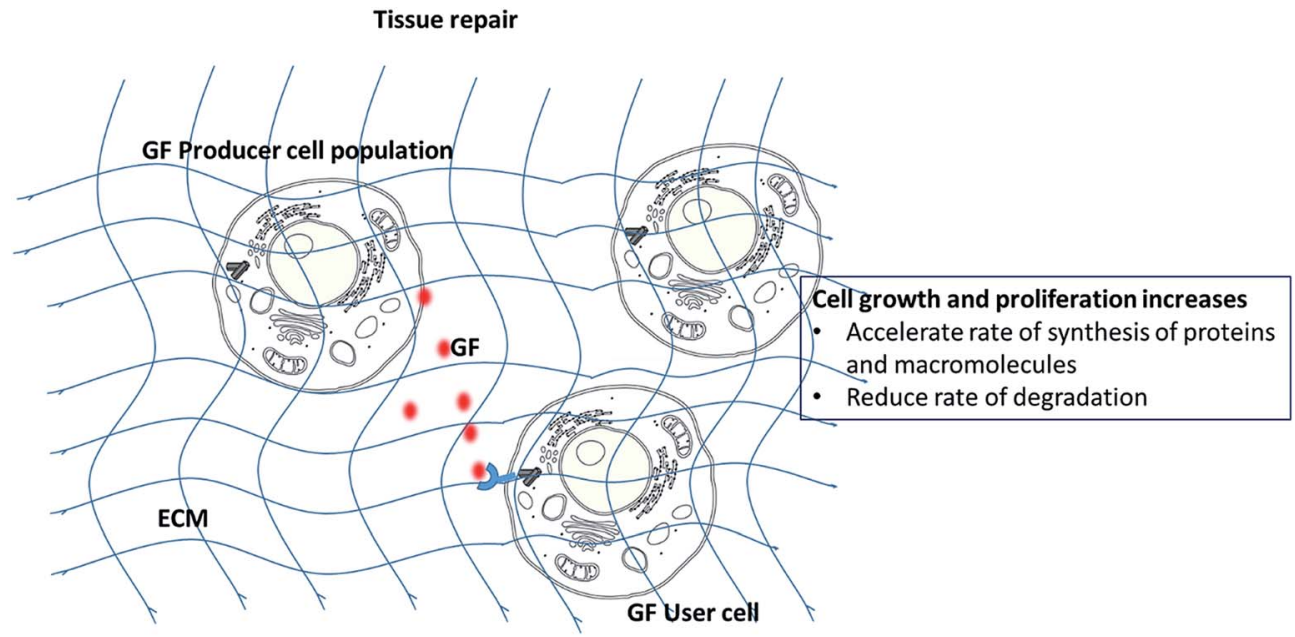

Scheme 1 Mechanism of action of GFs.

scaffolds and finally match the action of small molecules with specific growth factors in targeted tissue repair.

\section{Growth factors in TE}

GFs are critical polypeptide molecules that mediate cross talk between cells and ECM. They exhibit short-range diffusion through the ECM and act locally owing to their short half-lives and slow diffusion. They deliver specific messages to a distinct subpopulation of cells depending on: the identity of the latter, ability of GFs to diffuse through the ECM, the target cell number, type of receptors and the intracellular signal transduction subsequent to factor binding. ${ }^{17}$ In addition, the ultimate response of a target cell to a particular GF can also be governed by external factors, including its ability to bind to ECM, ECM degradation, GF concentration and cell target location. ${ }^{18}$ Different GFs are involved in the regeneration of various tissues (Table 1 ).

\subsection{Main classes of growth factors in tissue repair}

2.1.1 Fibroblast growth factors (FGFs). There are 22 members of the FGF family with molecular mass from 17 to 34 $\mathrm{kDa}$ and sharing of $13-71 \%$ amino acid identity. ${ }^{20}$ FGFs have a high affinity for heparan sulfate proteoglycans and require heparan sulfate to activate one of four cell-surface FGF receptors via the RAS/MAP kinase signaling pathway. ${ }^{21}$ In adults, FGFs are homeostatic factors and function in tissue repair and response to injury. FGFs have various biological functions both in vivo and in vitro, including roles in mitogenesis, cellular migration, differentiation, angiogenesis, and wound healing. A subset of the FGF family, expressed in adult tissues, is

Table 1 GFs and their functions in the tissue regeneration process ${ }^{19}$

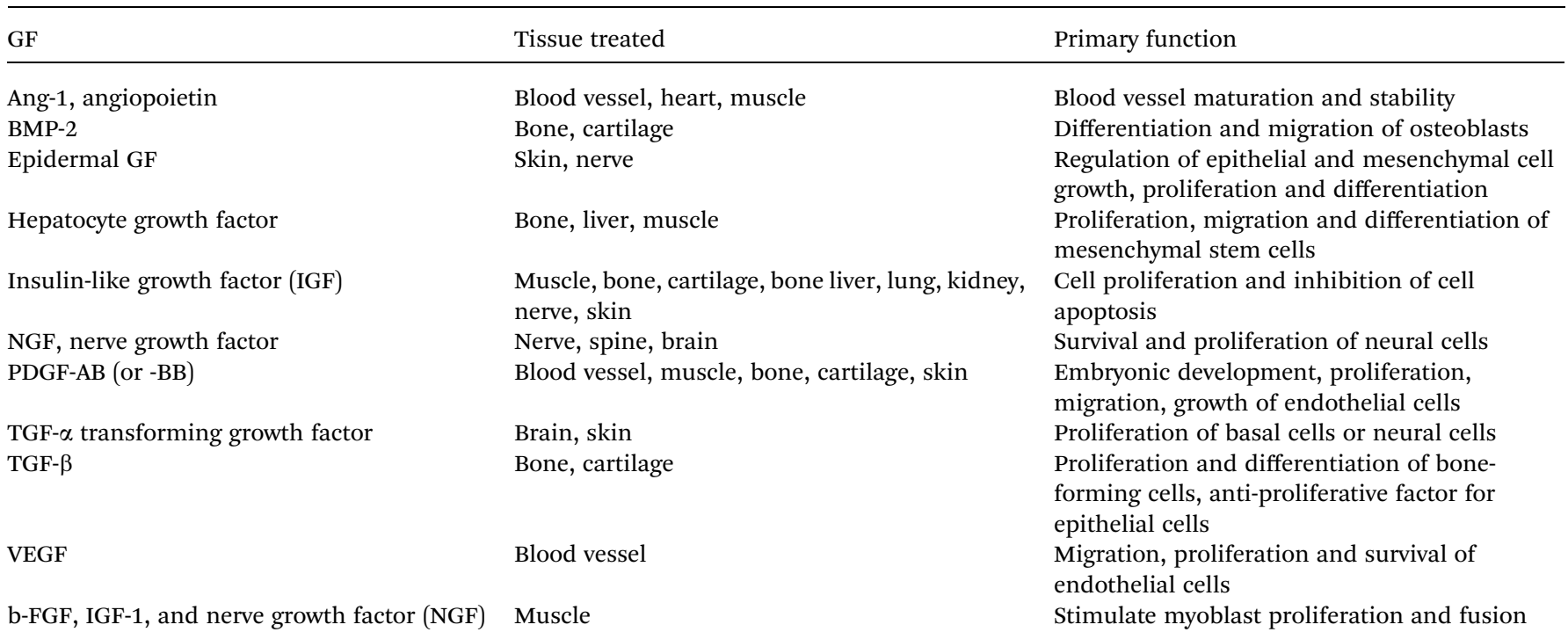


important for neuronal signal transduction in the central and peripheral nervous systems.

In Japan, human recombinant bFGF has been used clinically for chronic skin ulcers since $2001 .^{22}$ However, free-FGFs degrade readily in vivo, leading to loss of biological activity and functions. ${ }^{23}$ FGFs have been encapsulated/incorporated into scaffolds and have been used to regenerate damaged tissues, including skin, blood vessel, muscle, adipose, tendon/ligament, cartilage, bone, tooth, and nerve. ${ }^{21}$

2.1.2 Bone morphogenetic proteins (BMPs). BMPs belong to the transforming growth factor $\beta$ (TGF- $\beta$ ) superfamily. ${ }^{24}$ BMPs play an important role in maintaining adult tissue homeostasis, such as the maintenance of joint integrity, and vascular remodeling. They are also involved in postnatal cartilage and bone induction, maintenance and repair. ${ }^{25}$ Around 20 BMP family members have been identified and BMPs signal through serine/threonine kinase receptors, composed of type I and II subtypes. Although the term "BMP" implies that all members induce bone formation, some BMPs may inhibit bone formation. For instance, BMP3 is a negative regulator of bone density, and BMP13 is a strong inhibitor of bone formation. ${ }^{26}$ The pharmacokinetics of BMP action and the biologic outcome during wound repair is highly dependent on the dose administered and the release profile. Due to their osteogenic potential, BMPs have been used in various therapeutic interventions such as bone defects, non-union fractures, spinal fusion, osteoporosis and root canal surgery. ${ }^{25}$

However, BMPs are expensive and their use especially in spine fusion, may result in surgical site infection, wound complication, ectopic bone formation, local bone resorption, pseudoarthrosis, local edema and erythema, osteolysis, and nerve injury. ${ }^{27-32}$ Moreover, the application of rhBMP-2 led to critical complications such as inflammatory vessel fibrosis and scarring resulting in life-threatening vascular injury. ${ }^{29}$

Complication profile, likely related to the supra physiologic dose of BMP-2 delivered in one formulation ( $>40 \mathrm{mg}$ ) has led to safety concerns that now limits its clinical use. ${ }^{33}$ Reported complications include early inflammatory reaction and osteolysis, ectopic bone formation sometimes leading to compression of neural elements and seroma formation.

2.1.3 Vascular epithelial growth factor (VEGF). VEGF stimulates angiogenesis and also influences wound closure and epidermal repair, granulation tissue formation and the quality of repair. Activated fibroblasts, mast cells, keratinocytes and macrophages express VEGF during injury. ${ }^{34}$ VEGF functions by binding to VEGF tyrosine kinase receptors (VEGFR) on cell surface causing them to dimerize and become activated through transphosphorylation. This initiates multiple signaling pathways affecting cell proliferation, survival, migration, and tissue permeability. ${ }^{35}$ The levels of active VEGF protein tend to be abnormally low in individuals with chronic, non-healing wounds like those commonly observed in diabetic patients.

Maintaining local concentration of VEGF is crucial for angiogenic efficacy. It has been reported that in vitro and in vivo mouse models showed sequential vessel regression within 2 weeks after VEGF delivery. ${ }^{36}$ Thus, ECM and recruitment of mural cells are important to stabilize the nascent endothelial tubes and subsequently achieve capillary stability and durable arteriogenesis.

2.1.4 Platelet derived growth factor (PDGF). PDGF is a family of closely related $30 \mathrm{kDa}$ proteins made up of disulphide bonded A and B polypeptides. ${ }^{37}$ PDGF is originally derived from platelets, but it has also been isolated from a variety of normal and neoplastic tissues, including bone matrix and osteosarcoma cells. ${ }^{38-40}$ PDGFs have various important functions namely mitogenesis (increase in the cell populations of healing cells), angiogenesis (endothelial mitoses into functioning capillaries), and macrophage activation (debridement of the wound site and a second phase source of growth factors for continued repair and bone regeneration). ${ }^{\mathbf{4 1}}$ Furthermore, PDGF regulates skeletal growth and stimulates bone resorption. ${ }^{\mathbf{4 1}}$

Despite its beneficial roles in tissue development and repair processes, PDGF may also cause adverse reactions, such as malignancies and other conditions involving an excess of cell proliferation such as atherosclerosis and various fibrotic conditions like keloids. ${ }^{41,42}$ Therefore, the local delivery of PDGF is an important factor for its efficacy.

\subsection{Exogenous GFs in scaffolds}

Formulation of GFs, dose and route of administration are important parameters for their clinical success. ${ }^{43}$ The administration of supra physiological concentrations of GFs may lead to severe side effects owing to the extremely high initial concentration, and conversely may not allow sufficient levels of the factors to be sensed by target tissue for the necessary time frame owing to their rapid degradation and cleaving. For example, VEGF has a biological half-life of less than 30 minutes when infused intravenously, resulting in the need for massive doses and multiple injections. However, the use of large quantities of VEGF should be avoided because it could lead to catastrophic pathological vessel formation at non-target sites (e.g. dormant tumors).

To improve unsatisfactory outcomes in classical delivery of GFs, polymer matrices have been explored. Three main strategies have been developed for the incorporation of GFs within scaffolds namely via (i) chemical immobilization ${ }^{\mathbf{4 4 , 4 5}}$ and (ii) physical entrapment and (iii) physical encapsulation. ${ }^{46,47}$ In addition, recent advances now allow the release of GFs on demand by external/internal triggers enabling enhanced control. Release profiles of the GFs vary depending on the incorporation strategies. ${ }^{48}$

Incorporation of GFs within scaffolds has led to promising results. For instance, compared to the scaffold only, GF loaded scaffolds led to significantly enhanced in vivo wound healing, ${ }^{49}$ and bone formation. ${ }^{50}$ In an effort to mimic the natural microenvironment of tissue formation and repair, multiple GFs are being loaded into scaffolds and their release are being tailored such that the therapeutic agents are delivered at an optimized ratio, each at a physiological dose and in a specific spatiotemporal pattern. ${ }^{51}$

However, release of GFs can have detrimental effects if the delivery is not optimized properly. Indeed, as demonstrated by 
Walpoth et al., ${ }^{52}$ incorporation of VEGF within a fibrin matrix led to increased neo-intimal thickening during synthetic graft healing as a result of anastomotic ingrowth of endothelial and smooth muscle cells. Kawaguchi et al. ${ }^{53}$ conducted a randomized, placebo-controlled trial, investigating the direct application of FGF2 in a gelatin hydrogel on traumatic tibial fractures using low dose FGF $(0.8 \mathrm{mg})$ or high dose FGF $(2.4 \mathrm{mg})$ and placebo. Radiographic bone union was significantly higher in the FGF2 treated groups, with no significant difference between the two FGF2 dosage groups. One study has reported on a suture coated with PDLLA/VEGF used to heal meniscus tears in the avascular zone in sheep. It showed that the local application of VEGF via PDLLA-coated sutures did not promote meniscus healing. ${ }^{54}$

Despite the promising potential of GFs, a major limitation associated with their use involves immunogenicity which can induce pleiotropic effects such as the development of a high affinity B cell-mediated humoral response directed against the GFs. ${ }^{55}$ In addition, they have low half-life, are highly labile, expensive, have to be used in high doses and are linked with undesired side effects. ${ }^{15}$

\section{Small bioactive molecules for TE and their use in scaffolds}

Due to their unique advantages over GFs, small bioactive molecules (<1000 Da) are an important alternative to GFs. ${ }^{56,57}$ In particular, they are reproducibly synthesized through chemical reactions or extracted from organisms including plants. In addition, small molecules are unlikely to induce an immune response in the host because of their small size. ${ }^{58}$ Unlike polypeptides, the bioactivity of small molecules does not depend on their higher order structure. ${ }^{59}$ Additionally, they are usually uncharged and/or hydrophobic thereby facilitating their penetration through the phospholipid bilayer cellular membrane. ${ }^{\mathbf{6 0}}$
They can diffuse easily across the cellular membrane due to their small size. The use of small molecules $v s$. GFs significantly reduces the manufacturing cost and the risk of cross-species contamination. ${ }^{60}$ Therefore, small molecules with therapeutic potential represent the next generation of strategies for regenerative engineering. In this section, the influence of various small molecules on the bone repair process, chondrogenic differentiation, neuronal differentiation, adipogenic differentiation, as well as angiogenesis will be detailed with specific focus on the signaling pathways involved. Their use in scaffolds for sustained and localized release will also be discussed.

\subsection{Bone TE}

Normal bone metabolism is a complex sequence of bone formation (osteoblastogenesis) and bone resorption (osteoclastogenesis). The bone remodeling cycle involves osteoblasts (cells that produce organic bone matrix and aid in mineralization), osteoclasts (a unique cell type that dissolves bone mineral and enzymatically degrades ECM proteins) and osteocytes (osteoblast-derived post-mitotic cell within bone matrix that acts as a mechanosensor). ${ }^{61}$ Hormones such as PTH, calcitonin, growth hormones, sex hormones, thyroid hormones as well as steroids including vitamin $\mathrm{D}$ and glucocorticosteroids regulate bone metabolism by activation of signaling pathways (Fig. 1). Dickkopf-1 (DKK-1) and sclerostin inhibit osteoblast differentiation while insulin like GF (IFG-1) promotes the formation of osteoblasts. PTH stimulates osteoblasts to secrete sRANKL which in turn results in the activation of osteoclasts. OPG is a competitive inhibitor of SRANKL and thus blocks the latter from activating osteoclasts. High $\mathrm{Ca}^{2+}$ ion level in blood triggers the release of calcitonin from the thyroid gland. Calcitonin stimulates calcium salt deposit in bone. At low $\mathrm{Ca}^{2+}$ ions in blood, the thyroid gland releases PTH which stimulates

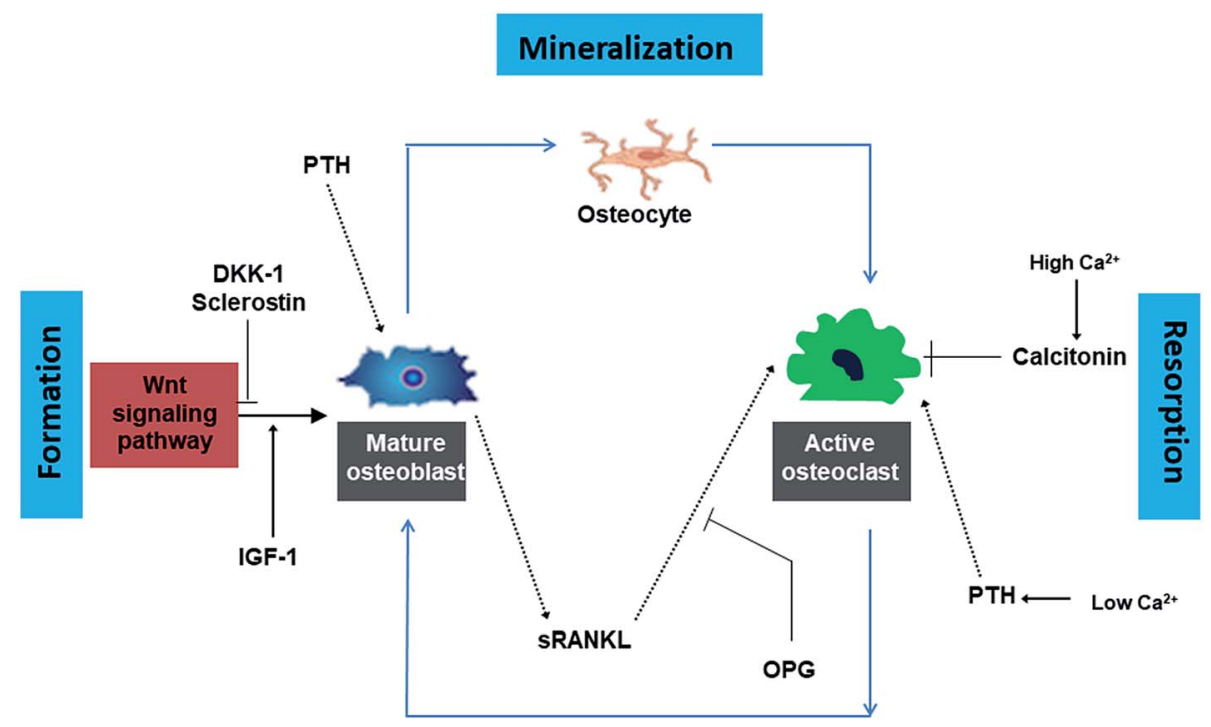

Fig. 1 Summary of the complex cycle of bone growth and resorption orchestrated by the dynamic relationship between osteoclasts, osteoblasts and an array of hormonal and regulatory influences. 
osteoclasts to degrade bone matrix to release calcium ions in the blood.

GFs improve bone formation by acting on specific signaling pathways involved in bone metabolism. Similarly, small molecules capable of activating specific signaling pathways related to bone formation may be useful for BTE applications. In the following sections, we discuss the effects of various small molecules on bone tissue regeneration when used either on their own or in combination with scaffolds.

3.1.1 Improved osteoconduction, osteoinduction and osteointegration

Bioceramics: hydroxyapatite, tricalcium phosphate, bisphosphonates, bioactive glass, akermanite. Bioceramics, an important class of biomaterials have been found to be osteoconductive, osteointegrative and to possess high compressive strength.6. Hydroxyapatite (HA) which is a central component of native bone is well known for its high bioactivity and osteoconductive properties. The osteoinductivity of HA has been primarily attributed to the interaction of biomaterials with the surface molecules of osteo-progenitor cells, i.e., integrin superfamily ${ }^{63}$ and focal adhesion components. ${ }^{64}$ These interactions in turn trigger cytoskeletal rearrangement ${ }^{64}$ and multiple intracellular signaling cascades. $\beta$ Tricalcium phosphate ( $\beta$-TCP) is a bioceramic material which has been widely used for hard tissue repair due to its bone-like chemical composition as well as excellent biological properties, including biocompatibility and osteoconductivity. A current clinical challenge in the field of BTE is to achieve neo bone integration with the native bone. In case of poor osteointegration, micromotions occur at the neo bone-native bone interface activating osteoclasts, which later leads to loosening and wear. ${ }^{65,66}$ Recent data have shown that bisphosphonate (BP) coating of bone implants may be an interesting solution. BPs increase bone density, which leads to a better bone integration. ${ }^{67,68}$ Bioactive glasses are amorphous in nature, have different families and each family has a specific composition. They are considered to be osteoconductive as well as osteoinductive. ${ }^{69}$ Recently akermanite ceramics have also received much interest due to their bone like apatite formation ability and good bioactivity. ${ }^{70}$

Following a comparative in vivo study of commercially available HA (Neobone®), carbonated apatite (Cytrans ${ }^{\circledR}$ ) and $\beta$ TCP (Cerasorb®), it was found that carbonated apatite (Cytrans $\left.{ }^{\circledR}\right)$ performed better than TCP and HA. Indeed, larger amount of bone was formed in the defects reconstructed with Cytrans ${ }^{\circledR}\left(\mathrm{CO}_{3} \mathrm{Ap}\right)$ and new bone formation in Cytrans ${ }^{\circledR}$ $\left(\mathrm{CO}_{3} \mathrm{Ap}\right)$ reached more central areas of the defects compared to those in Neobone ${ }^{\circledR}$ (HAp) and Cerasorb ${ }^{\circledR}(\beta-\mathrm{TCP})$ (Fig. 2).$^{71}$ In addition, highest inflammatory response and more granulation tissue were noted in Neobone ${ }^{\circledR}$ (HAp) followed by Cerasorb ${ }^{\circledR}(\beta-$ TCP) and Cytrans ${ }^{\circledR}\left(\mathrm{CO}_{3} \mathrm{Ap}\right)$. In another study, the performance of HA was compared with TCP and bioactive glass. ${ }^{72}$ It was found that both HA and TCP significantly improved osteogenesis (amount of bone) compared to bioactive glass. ${ }^{72} \mathrm{HA}$ led to highest number of blood vessels but the result was not significantly different with TCP. However, no difference in bone remodeling and remineralization was noted among the three materials as confirmed from osteonectin staining. Moreover,
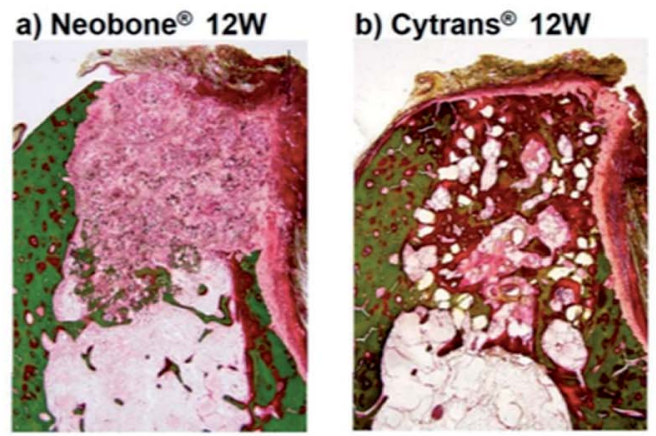

d) Neobone $\left.{ }^{\circledR} 12 \mathrm{~W}(\mathrm{x} 100) \mathrm{e}\right)$ Cytrans $^{\circledR} 12 \mathrm{~W}(\mathrm{x} 100)$

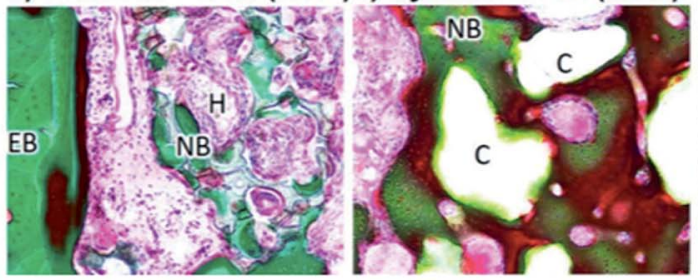

(A)
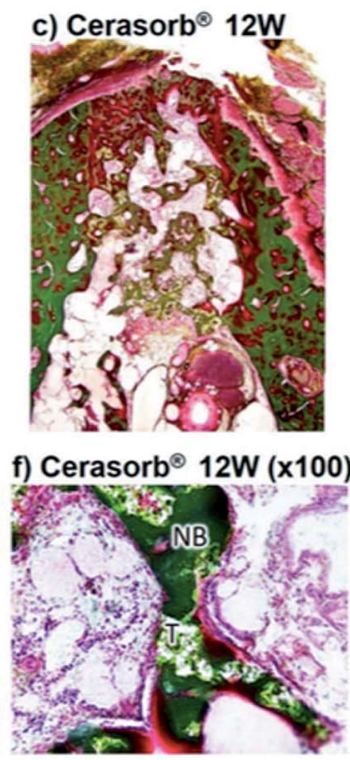

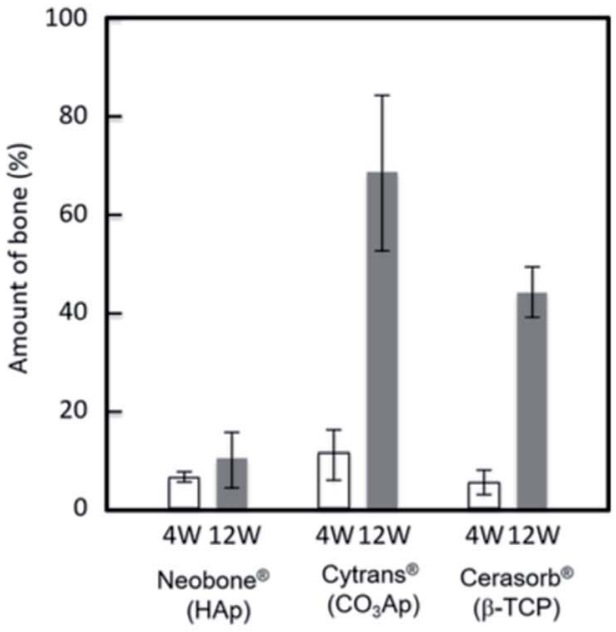

(B)

Fig. 2 (A) Histological findings of Neobone ${ }^{\circledR}(\mathrm{HAp})$, Cytrans ${ }^{\circledR}\left(\mathrm{CO}_{3} \mathrm{Ap}\right)$, and Cerasorb $\circledast$ implanted into dog mandibular bone defect at 12 weeks after implantation (Villanueva Goldner staining). Green area, dog mandibular bone defect at 12 weeks after implantation (Villanueva Goldner staining). Green area, dog mandibular bone defect at 12 weeks after implantation (Villanueva Goldner staining)®. $₫ G$ Green area, bone; red area, osteoid. EB, existing bone; NB, new bone; O, osteoid; $\mathrm{H}, \mathrm{HAp}$ (Neobone); $\mathrm{C}, \mathrm{CO}_{3} A$ p bone; red area, osteoid. EB, existing bone; NB, new bone; O, osteoid; $\mathrm{H}$, Hap (Neobone); C, $\mathrm{CO}_{3} \mathrm{Ap}$ (Cytrans); T, $\beta$-TCP (Cerasorb) and (B) amount of new bone formed in bone defect area at 4 weeks and 12 weeks after implantation. Reproduced from ref. 70 . This article is an open access article distributed under the terms and conditions of the Creative Commons Attribution (CC BY) license. 
Table 2 Mechanism of action of bioceramics on the promotion of bone formation

\begin{tabular}{|c|c|c|c|c|}
\hline Bioceramic & Formula & Pathway & $\begin{array}{l}\text { Effect on bone formation/ } \\
\text { metabolism }\end{array}$ & Ref. \\
\hline Hydroxyapatite (HA) & $\mathrm{Ca}_{10}\left(\mathrm{PO}_{4}\right)_{6}(\mathrm{OH})_{2}$ & $\begin{array}{l}\text { ERK/Sox } 9 \text {, BMP/Smad, Wnt, } \\
\text { MAPK, Notch }\end{array}$ & $\begin{array}{l}\text { - Induces in vivo bone matrix } \\
\text { mineralization, and } \\
\text { enhances bone-implant } \\
\text { osteointegration } \\
\text { - Achieves superior bone } \\
\text { quality and prevents fibrous } \\
\text { healing of bone }\end{array}$ & $74-78$ \\
\hline $\begin{array}{l}\beta \text {-Tricalcium phosphate }(\beta- \\
\text { TCP) }\end{array}$ & $\mathrm{Ca}_{3}\left(\mathrm{PO}_{4}\right)_{2}$ & BMP & $\begin{array}{l}\text { - Full thickness bone } \\
\text { ingrowth and well } \\
\text { vascularized bone tissue }\end{array}$ & 79 \\
\hline Bisphosphonate (BP) & $\left(\mathrm{PO}(\mathrm{OH})_{2}\right)$ & RANK & $\begin{array}{l}\text { - Increase bone density, } \\
\text { which leads to a better bone } \\
\text { integration } \\
\text { - Improved bone mass, } \\
\text { trabecular architecture } \\
\text { promoted apoptosis of } \\
\text { osteoclasts thereby reducing } \\
\text { bone resorption }\end{array}$ & $80-84$ \\
\hline Akermanite & $\mathrm{Ca}_{2} \mathrm{MgSi}_{2} \mathrm{O}_{7}$ & MAPK & $\begin{array}{l}\text { - Increased osteoblastic } \\
\text { activity as indicated by } \\
\text { higher osteoid secretion } \\
\text { - Good osteointegration }\end{array}$ & 85 \\
\hline Bioactive glass & $\begin{array}{l}45 \mathrm{~S} 5 \mathrm{Bioglass} 囚-45 \% \text { silica } \\
\left(\mathrm{SiO}_{2}\right), 24.5 \% \text { calcium oxide } \\
(\mathrm{CaO}), 24.5 \% \text { sodium oxide } \\
\left(\mathrm{Na}_{2} \mathrm{O}\right) \text {, and } 6 \% \\
\text { phosphorous pentoxide } \\
\left(\mathrm{P}_{2} \mathrm{O}_{5}\right)\end{array}$ & MAPK & $\begin{array}{l}\text { - Robust in vivo bone in } \\
\text { growth throughout the } \\
\text { porous scaffold while } \\
\text { maintaining bone-material } \\
\text { contact without ectopic bone } \\
\text { formation }\end{array}$ & 86 and 87 \\
\hline
\end{tabular}

akermanite possessed superior osteoinductive activity, bone formation potential, and also stimulated angiogenesis and inhibited osteoclastogenesis compared to $\beta$-TCP bioceramics. ${ }^{73}$

Table 2 summarizes the most common bioceramics used and their effect on bone formation.

Bioceramics may be used as scaffold materials ${ }^{88}$ or as additives to scaffolds. In clinic, bioceramic scaffolds should be able to function for the remaining years of the patient's life. This is dependent on the interface created with the living tissue since loosening of the implants can occur due to interfacial movement leading to clinical failure (fracture of the implant or the bone adjacent to the implant). ${ }^{89}$ In order to match the mechanical properties and elastic constants of bone, bioceramics are combined with polymers and metals.

As discussed earlier, HA is an excellent candidate for bone repair and healing as it is the main mineral component of bone with a $\mathrm{Ca}: \mathrm{P}$ ratio of 1.67 . It has been used as additive in polymeric scaffolds to mimic the environment of cells involved in bone regeneration in the form of particles or scaffold itself (Table 3). Nano-HA is being used in prosthetic applications due

Table 3 Some reported HA-containing scaffolds and their bio-performance

Polymeric scaffold
PLLA/nanohydroxyapatite nHAP particles
dispersed in the pore walls of the scaffolds
Collagen-hydroxyapatite scaffolds containing
PLGA microparticles loaded with PTHrP, an
osteogenic pentapeptide

Photo-crosslinkable poly(trimethylene carbonate) (PTMC) resins containing 20 and $40 \mathrm{wt} \%$ of HA nanoparticles

Electrospun polylactic acid and HA covered with polypyrrole with iodine (PPy-I) synthetized by plasma polymerization
Bio performance

Ref.

Improved protein adsorption capacity

Enhanced osteogenesis as assessed by alkaline phosphatase production and osteocalcin and osteopontin gene expression in pre-osteoblastic cells

Robust bone formation in rabbit calvarial defect model, amount of HA governed osteogenesis mechanism

In vivo test in the back of a rabbit for 30 days High cell viability and integration using uniaxial tensile testing 
to its similarity in size, crystallography and chemical composition with human hard tissue.

Statins. Since the discovery of the impact of statins on bone formation in 1999, much research has been conducted on the osteogenic properties of this family of compounds. ${ }^{94}$ The osteogenic potential of statins may be attributed to their ability to activate the BMP-signaling pathway. When given orally, statins are subjected to first-pass metabolism in the liver ${ }^{95}$ and when injected locally, they disperse quickly and have short halflives. ${ }^{94}$ Therefore, to optimize their efficacy, statins have been incorporated into scaffolds.

Lovastatin, rosuvastatin, simvastatin (Fig. 3A-C) etc are a few of the statins family which have been studied for bone regeneration. Lovastatin containing scaffolds was found to significantly enhance osteogenic differentiation of osteoblastic cells in vitro as shown by alkaline phosphatase (ALP) staining. ${ }^{96}$ In addition, the bone defect was filled to a larger extent with the use of lovastatin loaded polyurethane (PU) scaffolds compared to the pure PU only. Incorporation of rosuvastatin into TCP scaffolds resulted in higher bone volume and increased bone mineral density after implantation in a critical sized tibial defect in rabbits. ${ }^{97}$ In another study, simvastatin loaded PLGA fibers promoted osteoblastic differentiation of BMSCs in vitro and suppressed bone resorption in vivo. ${ }^{98}$ Addition of simvastatin significantly increased the newly formed bone area ${ }^{99}$ and neovascularization ${ }^{\mathbf{1 0 0}}$ compared to the unloaded controls.

Strontium and vanadium compounds. Strontium $(\mathrm{Sr})$ has been found to rebalance bone turnover by dually promoting bone formation as well as bone resorption. ${ }^{\mathbf{1 0 1}}$ More specifically, $\mathrm{Sr}$ in the form of strontium ranelate for example led to enhanced in vitro pre-osteoblast cell proliferation and collagen synthesis. On the other hand, it reduced osteoclast differentiation. Overall, these effects led to increased in vivo bone mass and improved microarchitecture, bone geometry and bone resistance. ${ }^{\mathbf{1 0 2}}$ Strontium ranelate also promoted mineralization of murine bone marrow stromal cells (BMSCs) by increasing prostaglandin levels. The rate of $\mathrm{Sr}$ released from a given biomaterial influences its activity, since osteoblast-like cells use the strontium released from the biomaterial to synthesize their mineralized ECM. ${ }^{103}$ Low amounts of $\mathrm{Sr}(0.1 \%)$ was found to significantly stimulate in vitro proliferation of pre-osteoblasts and endothelial cells, improve the bone-bonding ability and oxidative balance stability in vivo. ${ }^{\mathbf{1 0 4}}$

The trace element vanadium is present at low concentrations $\left(10^{-8} \mathrm{~mol} \mathrm{~L}^{-1}\right)$ in practically all cells. ${ }^{105}$ It exists in various oxidation states from -1 to +5 and at pharmaceutical doses, vanadium III, IV and v compounds display relevant biological actions such as mimicking insulin and GFs. Vanadium compounds affect bone turnover since they are mainly stored in bone. ${ }^{105}$ Recently, vanadium(Iv)-ascorbic acid complex was found to stimulate osteoblast differentiation and mineralization in vitro, suggesting its osteogenic potential. ${ }^{106}$ Furthermore, collagen I production in osteoblasts was dependent on the dose of the vanadium compound. ${ }^{\mathbf{1 0 6}}$

3.1.2 Improved osteoblastogenesis and inhibition of osteoclastogenesis

Flavonoids. Plants are a major source of several structurally important phytochemicals which may be classified into alkaloids, carotenoids, organosulphurs, phenols and phytosterols. ${ }^{107}$ Amongst phenolic compounds, flavonoids are the largest and most studied compounds and may be found in

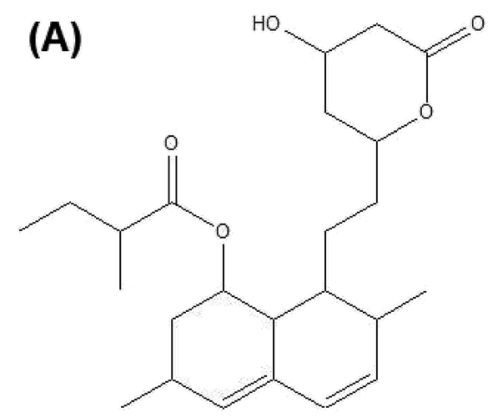

(C)<smiles>CCC(C)(C)C(=O)OC1CC(C)C=C2C=CC(C)C(CCC3CC(O)CC(=O)O3)C21</smiles>

(B)<smiles>CC(C)c1nc(N(C)S(C)(=O)=O)nc(-c2ccc(F)cc2)c1/C=C/C(O)CC(O)CC(=O)O</smiles>

(D)<smiles>c1ccc(C2CCc3ccccc3O2)cc1</smiles>

Fig. 3 (A) Lovastatin, (B) rosuvastatin, (C) simvastatin and (D) general chemical backbone of flavonoids. 
fruits, vegetables, barks, roots, stems, flowers and grains (Fig. 3D). Flavonoids display various biological/ pharmacological properties such as anti-oxidant, antiangiogenic, anti-inflammatory and anti-viral properties which may be beneficial for BTE scaffolds. ${ }^{\mathbf{1 0 8}}$ Most flavonoids promote osteoblastogenesis which eventually leads to bone formation ${ }^{\mathbf{1 0 9}}$ while others prevent bone resorption and bone loss through inhibition of osteoclastogenesis. ${ }^{110}$ More specifically, flavonoids improve osteogenesis by promoting mesenchymal stem cells (MSCs) and pre-osteoblasts differentiation into osteoblasts through MAPK signaling. ${ }^{111,112}$ They also stimulate the expression of osteogenic transcription factors and markers through various signaling pathways including Wnt and MAPK signaling. ${ }^{113}$

Icariin (Table 4), a bioactive flavonoid extracted from the Chinese medicinal plant Herba Epimedii, has been shown to promote osteoblasts differentiation, and inhibit osteoclast differentiation. ${ }^{\mathbf{1 1 4 , 1 1 5}}$ In order to enhance repair of bone defects, icariin was loaded into TCP disks. Addition of icariin did not influence the attachment and morphology of osteoblast-like cells but increased their proliferation, differentiation and in vivo bone formation, thereby indicating its osteoinductive property. ${ }^{116}$ Interestingly, icariin when incorporated within a chitosan/HA construct led to favorable in vivo osteoconduction, osteoinduction and stimulated new bone tissue formation at an early stage. ${ }^{\mathbf{1 1 7}}$ Icariin displayed a dose dependent effect with a higher dose leading to more mineralized bone nodules and higher levels of calcium deposition. ${ }^{118}$ Icariin also inhibited the bone resorption activity of osteoclasts, suggesting its potential to be used as an additive to strengthen bone. Vascularization in BTE which is considered as a major challenge could possibly be overcome by addition of icariin. Indeed, icariin promoted in vitro endothelial cell proliferation, migration, and tubulogenesis, as well as increased in vivo angiogenesis. ${ }^{\mathbf{1 1 9}}$

The small polyphenolic molecule, resveratrol was recently shown to be highly beneficial for bone development and growth. In particular, in vitro studies demonstrated that in the presence of resveratrol, both ALP and prolyl hydroxylase activities were increased in pre-osteoblastic cells ${ }^{\mathbf{1 2 0}}$ while the development of osteoclasts was inhibited. Resveratrol (Fig. 4A) could also boost the osteogenic potential of adipose tissue derived stem cells (ATMSCs). ${ }^{121}$ Dosages as small as $0.1 \mu \mathrm{M}$ were conducive for stem cell renewal while dosages above $5 \mu \mathrm{M}$ inhibited cellular renewal. ${ }^{122}$ All dosages were osteogenic, with a dose dependent effect. Preliminary studies suggested that a burst release system might be ideal for the delivery of resveratrol. ${ }^{123}$ The influence of resveratrol on in vivo bony defects was studied for the first time by Li et al. ${ }^{\mathbf{1 2 4}}$ Resveratrolloaded polycaprolactone (PCL) scaffolds showed significantly higher bone formation ( $25 \%$ vs. $10 \%$ ) with greater bone density and higher immunostaining for mature bone markers compared to the unloaded scaffolds. ${ }^{\mathbf{1 2 4}}$

Kaempferol (Fig. 4B) when incorporated within a layer by layer (LbL) matrix was shown to increase the mineralization of BMCs in vitro, as evidenced from increased nodule formation. ${ }^{125}$ Moreover, in vivo implantation resulted in increased bone stiffness after 1 month compared to the sham or LbL only groups. In another study, surface modification of scaffolds with catechin (Fig. 4C) not only improved cell adhesion and proliferation (Fig. 5A) but also significantly increased in vitro (Fig. 5B) and in vivo osteogenesis of hADSCs as a result of the intrinsic biochemical properties of catechin, namely reactive oxygen species (ROS) scavenging and high calcium binding affinity. ${ }^{\mathbf{1 2 6}}$ Hesperetin (Table 4), a subgroup of flavanones could promote osteogenic differentiation of human MSCs in vitro via activation of the ERK and Smad signaling pathways. In vivo, a hesperetin/ gelatin scaffold led to complete fracture union without cortical gap in contrast to the pure gelatin scaffold whereby minimal bone growth was noted. ${ }^{\mathbf{1 2 7}}$ Following studies revealing the beneficial effects of naringin (Fig. 4D) on bone metabolism, Chen et al. ${ }^{\mathbf{1 2 8}}$ fabricated gelatin/TCP/naringin scaffolds and evaluated their potential to repair bone defects. It was found that naringin significantly enhanced the proliferation of osteoblasts and led to more bone formation in vivo. In line with this study, the controlled release of naringin from electrospun PCL/ PEG- $b$-PCL improved osteoblast adhesion, proliferation, differentiation, mineralization and suppressed osteoclast formation. ${ }^{129}$

Table 4 gives a summary of in vitro and in vivo effects of some flavonoids on bone formation. However, few flavonoids have been found to induce controversial effects in bone. For instance, Kim et al. reported that the flavonoid quercetin increased osteogenic differentiation of human adipose tissuederived stromal cells (hADSC) by inhibiting their proliferation. ${ }^{130}$ In contrast, Notoya et al. demonstrated that quercetin reduced the level of osteogenic differentiation markers such as ALP and osteocalcin. ${ }^{\mathbf{1 3 1}}$ Similarly, the polyphenol, apigenin (Fig. 4E) inhibited both osteoblastogenesis and osteoclastogenesis in MC3T3-E1 cells and OVX mice. ${ }^{\mathbf{1 3 2}}$

Nevertheless, overall studies indicated that flavonoids may be a potent additive for bone tissue growth and prevention of bone loss.

Purmorphamine. Purmorphamine, (2,6,9-trisubstituted purine) was found to induce osteogenesis in mouse mesenchymal progenitor cells ${ }^{\mathbf{1 4 6}}$ and adipose tissue derived stem cells (ATMSCs). ${ }^{147}$ In a comparative study between purmorphamine and BMP-4, the small molecule was found to increase osteogenesis to an extent similar to BMP-4 by using a pathway distinctly different from the latter. Both purmorphamine and BMP-4 increased cellular proliferation and upregulation of several cell cycle regulators. However, BMP-4 induced genes for adipogenic and osteogenic differentiation while purmorphamine up-regulated osteogenic genes while simultaneously lowering the adipogenic differentiation. This suggests the ability of purmorphamine to induce osteogenic differentiation selectively. ${ }^{\mathbf{1 4 6}}$ The bioactivity of purmorphamine was tested for the first time in vivo in 2013 whereby porous calcium phosphate beads were used to deliver this small molecule. ${ }^{148}$ Results revealed significantly increased bone growth at the implant-site of the beads soaked in purmorphamine $v s$. the control beads. However, purmorphamine failed to induce any significant difference in osteointegration suggesting that the latter might be useful for enhancing bone regeneration where bone loss due 
Table 4 In vitro and in vivo effects of flavonoids on BTE

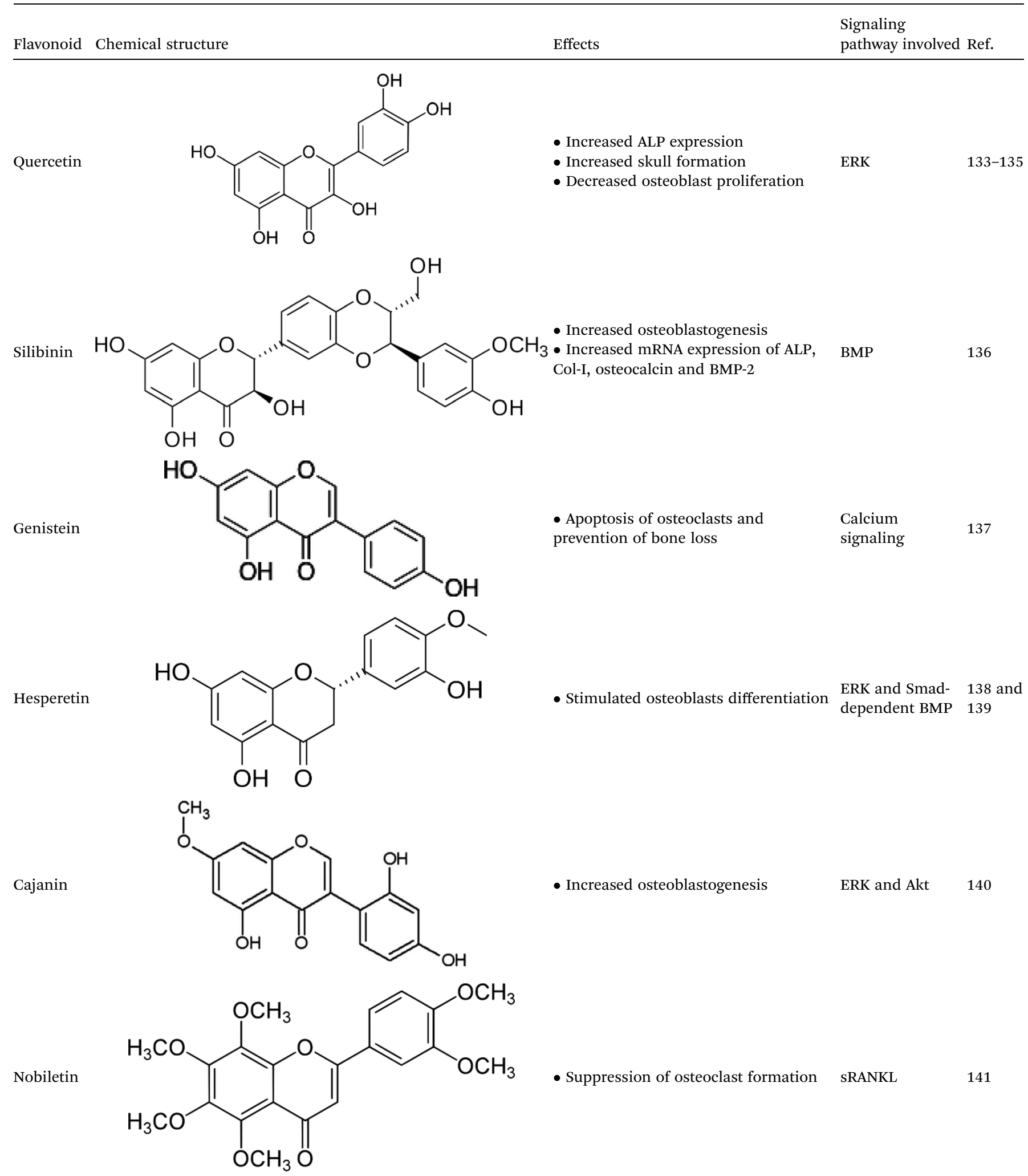


Table 4 (Contd.)<smiles>COc1ccc(-c2oc3c(CC=C(C)C)c(OC4O[C@H](CO)[C@@H](O)[C@H](O)[C@H]4O)cc(O)c3c(=O)c2OC2O[C@H](C)[C@@H](O)[C@H](O)[C@H]2O)cc1</smiles>

to disease exists, and not for enhancing early stability of an implant. ${ }^{148}$

3.1.3 Simultaneous osteogenesis and angiogenesis. Vascularization plays an important role in bone healing process by ensuring the formation of blood vessels to transport nutrients, oxygen, osteogenic factors and stem cells to the newly forming bone. This process is controlled by various GFs (VEGF
- Increased BMP-2 synthesis

- Induction of osteoblast maturation and $\mathrm{Smad1/5/8}$ and

differentiation ERK1/2 142

- Increased bone mass

- Promoted bone cell proliferation

- Stimulated ALP activity and formation ERK, MAPK

143-145

of mineralized nodules

- Increased bone mineral density, bone

trabecular number and thickness<smiles>Oc1ccc(/C=C/c2cc(O)cc(O)c2)cc1</smiles>

A<smiles>O=c1c(O)c(-c2ccc(O)cc2)oc2cc(O)cc(O)c12</smiles>

B<smiles>Oc1cc(O)c2c(c1)O[C@H](c1ccc(O)c(O)c1)[C@H](O)C2</smiles>

C

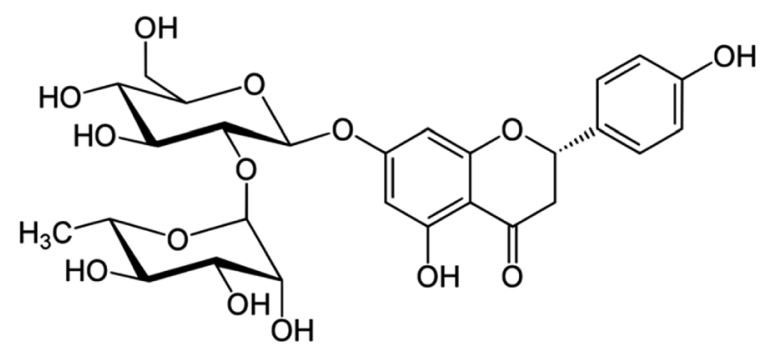

D<smiles>O=c1cc(-c2ccc(O)cc2)oc2cc(O)cc(O)c12</smiles>

$\mathbf{E}$

Fig. 4 Chemical structure of (A) resveratrol (B) kaempferol (C) catechin and (D) naringin (E) apigenin. 
A No coating

\section{Catechin}
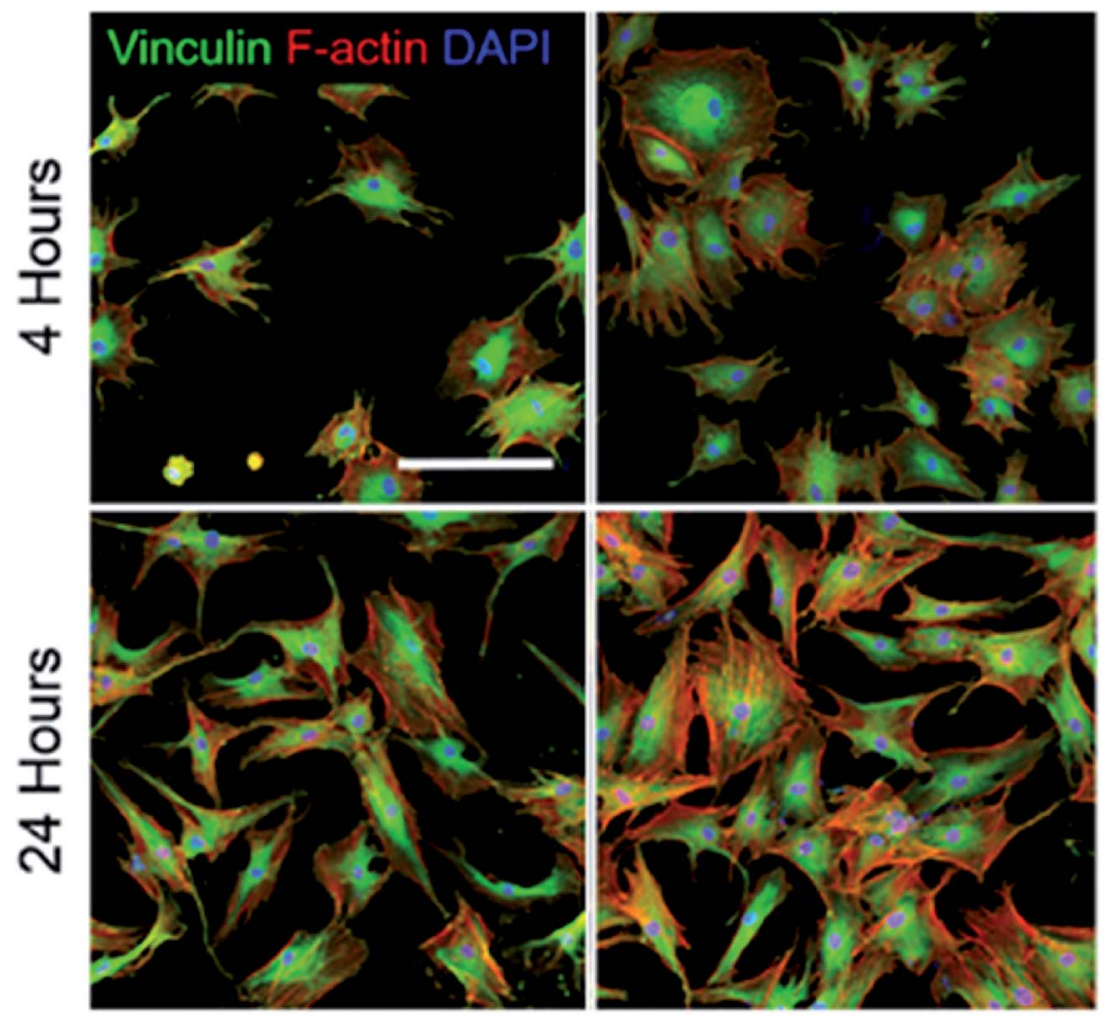

\section{B}
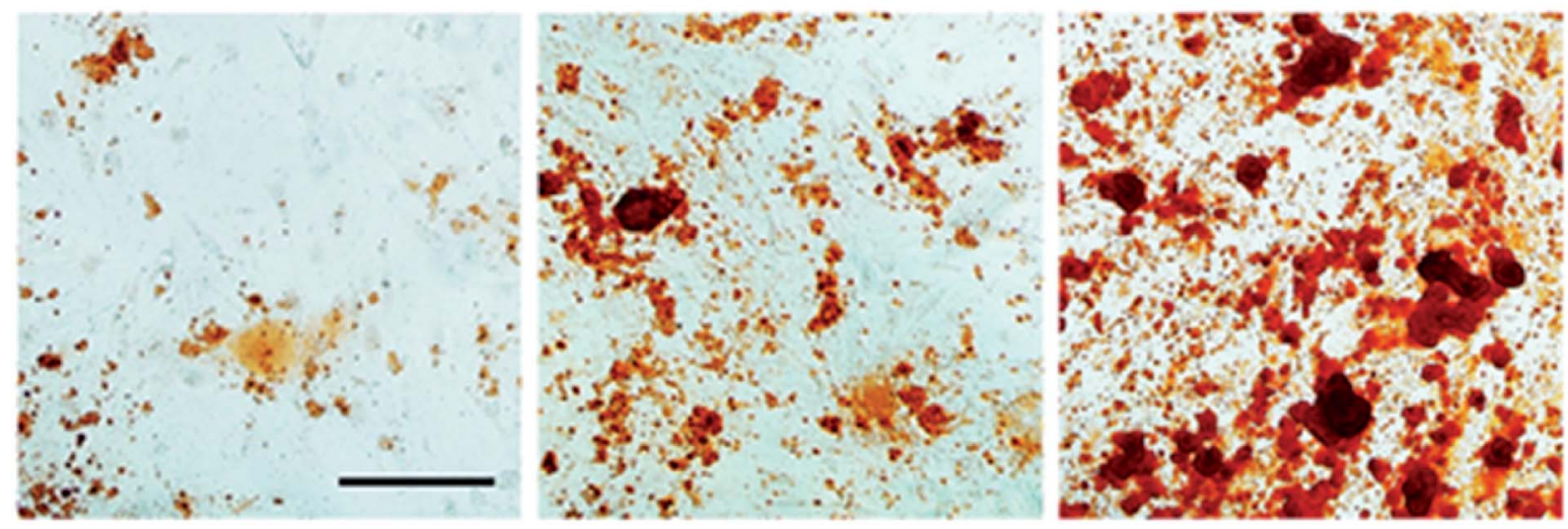

Fig. 5 (A) Immunofluorescent staining of vinculin (green), F-actin (red), and DAPI (blue). Scale bar $=100 \mu \mathrm{m}$. And (B) alizarin red staining for evaluating calcium deposition of osteogenically differentiated hADSCs (scale bar $=200 \mu \mathrm{m}$ ). Adapted with permission from ref. 126.

angiogenesis and osteogenesis and therefore could be used as alternatives to multi-growth factor delivery strategies.

FTY720, an immuno-modulating drug derived from the natural product myriocin enhanced neovascularization and new bone formation in a rat model when delivered via PLGA scaffolds. ${ }^{152}$ FTY720 synergistically activates S1P1 and S1P3 (i.e. action mechanism of FTY720) which are crucial for microvascular growth and remodeling. However, local application of the molecule is necessary to realize the full therapeutic effect. Indeed, no significant difference in new bone formation was noted between the FTY720-treated and control animals when FTY720 was administered via subcutaneous injections. ${ }^{153}$

Statins have also been shown to upregulate osteoblast related genes and VEGF expressions in a time and concentration dependent manner. ${ }^{154,155}$ Further studies employing more clinically relevant models also confirmed the dual osteogenic and angiogenic properties of statins. ${ }^{156-158}$ 


\subsection{Cartilage TE}

Calcium silicate, a common additive for BTE was found to improve chondrogenic differentiation in vitro and in vivo by increasing the hydrophilicity of the resulting material and improving cell-material interactions. In vivo regenerated cartilage using poly(hydroxybutyrate-co-valerate) (PHBV)/calcium silicate displayed higher compressive modulus as a result of amounts of collagen and glucosaminoglycan (GAG) produced by chondrocytes. ${ }^{159}$ Icariin which was found to improve BTE was also shown to be effective for cartilage TE. ${ }^{\mathbf{1 6 0}}$ Indeed, the latter promoted ECM synthesis and the expressions of sox9, collagen type II (Col II) and aggrecan (AGG) genes of chondrocytes in vitro. Incorporation of icariin within collagen hydrogel enhanced the integration of the newly-formed cartilage. In vivo cartilage reconstruction using collagen hydrogels after 4 weeks demonstrated the limited formation of new cartilage with a large section of the surface filled with fibrous connective tissue. In contrast, a whole layer of new cartilage was formed with the use of icariin loaded collagen hydrogels. Icariin has also been chemically conjugated to hyaluronic acid/collagen hydrogel. ${ }^{161}$ The slow release of icariin effectively maintained the chondrocytes morphology and promoted the biosynthesis of cartilage matrix. A layer of chondroid tissue could be observed

\section{PHBV}

\section{PHBV-BG}

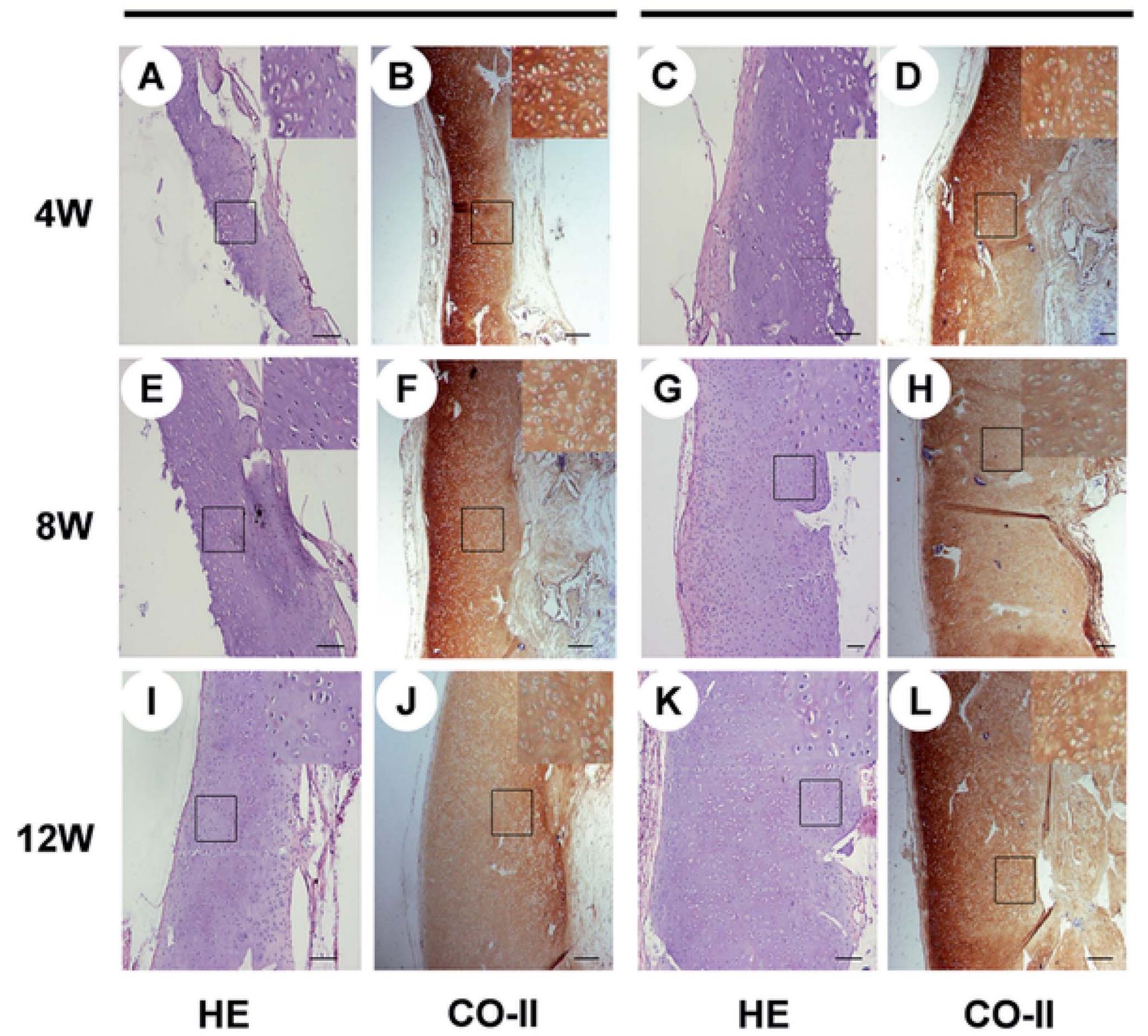

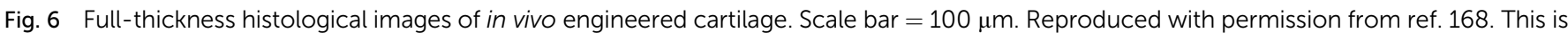

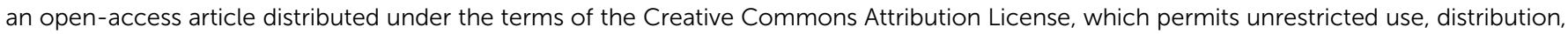
and reproduction in any medium, provided the original author and source are credited. 
<smiles>c1ccc2c(Oc3nc(Nc4ccc(N5CCOCC5)cc4)c4ncn(C5CCCCC5)c4n3)cccc2c1</smiles><smiles>[B]c1ccc(-c2nc(-c3ccc(-c4cccc(Cl)c4)o3)[nH]c2-c2ccc(OC)cc2)cc1</smiles><smiles>COc1ccc(C2CNC(=O)C2)cc1CC1CCCC1</smiles><smiles>CC1=C(CCC(C)CCCC(C)CC(=O)O)C(C)(C)CCC1</smiles>

Fig. 7 Chemical structure of (A) purmorphamine (B) neurodazine/neurodazole (C) rolipram (D) retinoic acid.

on the surface of hyaluronic acid/collagen/icariin construct while the scaffold without icariin showed cell clustering. Thicker layer of cartilage was observed on hyaluronic acid/ collagen/icariin after 21 days. In the hyaluronic acid/collagen/ icariin group, cells residing within the lacunae retained chondrocytic morphology while some cells were spherical in the hyaluronic acid/collagen group.

Curcumin (CUR), a polyphenol isolated from Curcuma longa has been reported to possess strong anti-oxidant, anti-tumor, anti-angiogenesis and anti-inflammatory properties. ${ }^{162}$ CUR was shown to inhibit IL-1 $\beta$-induced activation of NF- $\mathrm{KB}$, activation of caspase- 3 and cyclooxygenase- 2 in MSCs and chondrocytes in both time and concentration dependent manners. ${ }^{163,164}$ This resulted in inhibition of proteoglycan degradation, reduced chondrocyte apoptosis, enhanced production of collagen type II, cartilage specific proteoglycans (CSPGs), and $\beta 1$-integrin. ${ }^{165}$ Hence, incorporation of CUR within scaffolds allows establishing a microenvironment in which the effects of pro-inflammatory cytokines are antagonized, thereby facilitating the regeneration of articular cartilage. Indeed, major differences were noted following in vivo subcutaneous implantation of silk and silk/CUR scaffolds in mice whereby the silk/CUR scaffolds led to the formation of a uniform cartilaginous matrix. ${ }^{166}$

Bioglass (BG), an important bioceramic for BTE was found to be beneficial for cartilage TE. ${ }^{167}$ For instance, histological and immuno-histochemical analysis of regenerated tissue following implantation of PHBV and PHBV/bioglass (BG) scaffolds demonstrated higher collagen, GAG contents. The regenerated cartilage samples of PHBV and PHBV/BG groups differed significantly in terms of thickness, side length, volume and wet weight. In particular, thicker cartilage-like tissue layers were noted in the PHBV/BG group at different time points (Fig. 6). Blood vessel ingrowth and macrophage migration limit graft stability of immature constructs in cartilage TE via fast in vivo resorption. Therefore, anti-angiogenic therapies have been proposed as an adjuvant for successful cartilage TE. ${ }^{168}$ A hyaluronan/fibrin-based porous scaffold functionalized by a monoclonal anti-VEGF antibody (bevacizumab) was used to block VEGF. Scaffolds without bevacizumab had low in vivo stability. In particular, $82 \%$ of scaffolds without bevacizumab completely degraded after 6 weeks in vivo, most likely due to newly formed matrix remodeling and resorption on host vessel and monocyte invasion, which was already evident at 3 weeks on implantation. ${ }^{168}$ Moreover, strontium ranelate strongly stimulated proteoglycans production and human cartilage matrix formation in vitro by a direct ionic effect without<smiles>O=S(=O)(NCC1CC1)c1ccc(Nc2nccc(N3CCCc4cc(O)ccc43)n2)cc1</smiles>

Fig. 8 Chemical structure of pyrintegrin. 


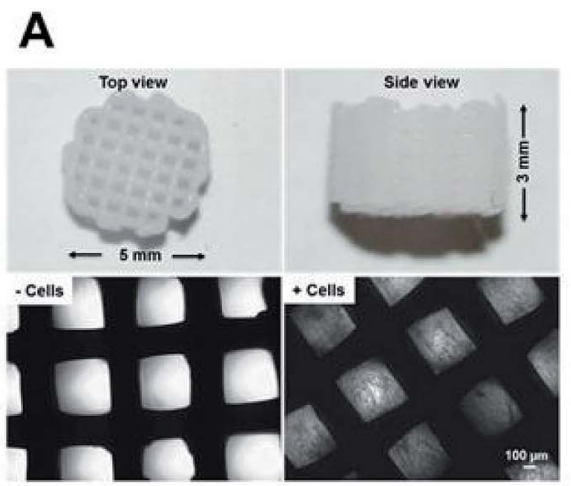

C

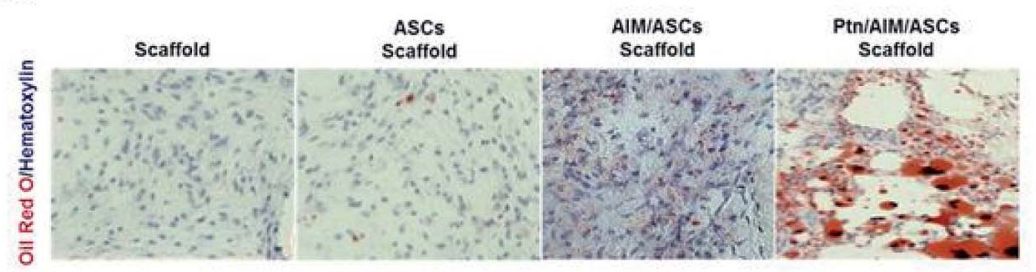

B

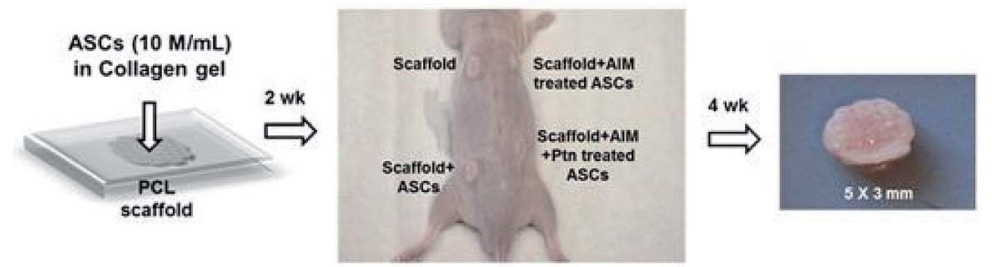

D

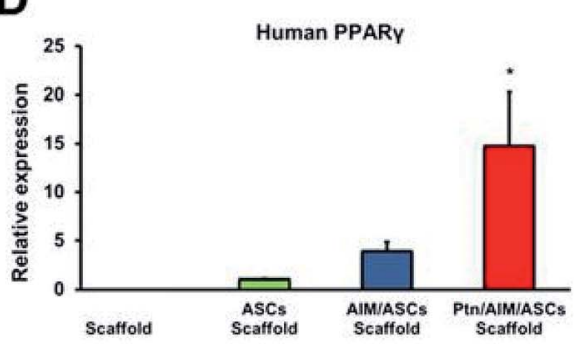

Fig. 9 (A) Polycaprolactone (PCL) particles were melted and 3D-printed as cylinders, with top and side views and microscopic images without and with cells seeded in microchannels. (B) Infusion of human adipose derived stem cells (hASCs) in collagen gel into PCL microchannels, followed by implantation in the dorsum of athymic mice and retrieved in 4 weeks, with a representative sample shown. (C) Representative histology images of in vivo retrieved samples stained for lipids by Oil-Red-O dye and nucleus by hematoxylin stain. (D) q RT-PCR analysis of human PPAR $\gamma$, of in vivo retrieved samples. Scale bar: $100 \mu \mathrm{m}$. Data are expressed as mean $\pm \mathrm{SD} * P<0.05$ (reproduced with permission from ref. 182). This work is licensed under a Creative Commons Attribution 4.0 International License.

stimulating the chondro-resorption processes. ${ }^{169}$ Additionally, it also decreased chondrocyte apoptosis. ${ }^{170}$

\subsection{Neural TE}

Neural stem cells (NSCs) often used to investigate neuronal differentiation are pluripotent cells with the ability to differentiate into three main neural cells namely neuron, astrocyte and oligodendrocyte. So far, only few small molecules such as retinoic acid, purmorphamine, rolipram have been investigated as additives to improve neuronal TE (Fig. 7).

Retinoic acid (RA) is a small lipophilic metabolite of vitamin A. Tan et al. showed that RA could promote the growth of cellular dendrites and neuronal differentiation of neural stem cells (NSCs), and eventually induced functional maturation of differentiated neurons. ${ }^{171}$ Purmorphamine is another small molecule which induced motor neuron specification via activation of the sonic hedgehog (SHH) pathway. ${ }^{172}$ The use of purmorphamine not only achieved high efficiency of differentiation of ventral spinal progenitors and motor neurons from human embryonic stem cells and decreased the cost but it also improved feasibility of large-scale production due to its stable chemical nature and easy preparation procedure. ${ }^{172}$ Other studies have studied the combined effect of RA and purmorphamine on neuronal differentiation. As reported by Binan et al., the controlled release of these two biomolecules from electrospun PLA/gelatin scaffold significantly increased cell growth and neurite length which was 8-fold longer after 14 days compared to the control. ${ }^{173}$ Rolipram, due to its antiinflammatory and cyclic adenosine monophosphate (cAMP) preserving properties has been found to promote the regeneration of new axons, ${ }^{174}$ aid in the preservation of myelinated tissues, ${ }^{175}$ attenuate acute oligodendrocyte death, ${ }^{176}$ reduce reactive gliosis and subsequent glial scar formation, ${ }^{177}$ and

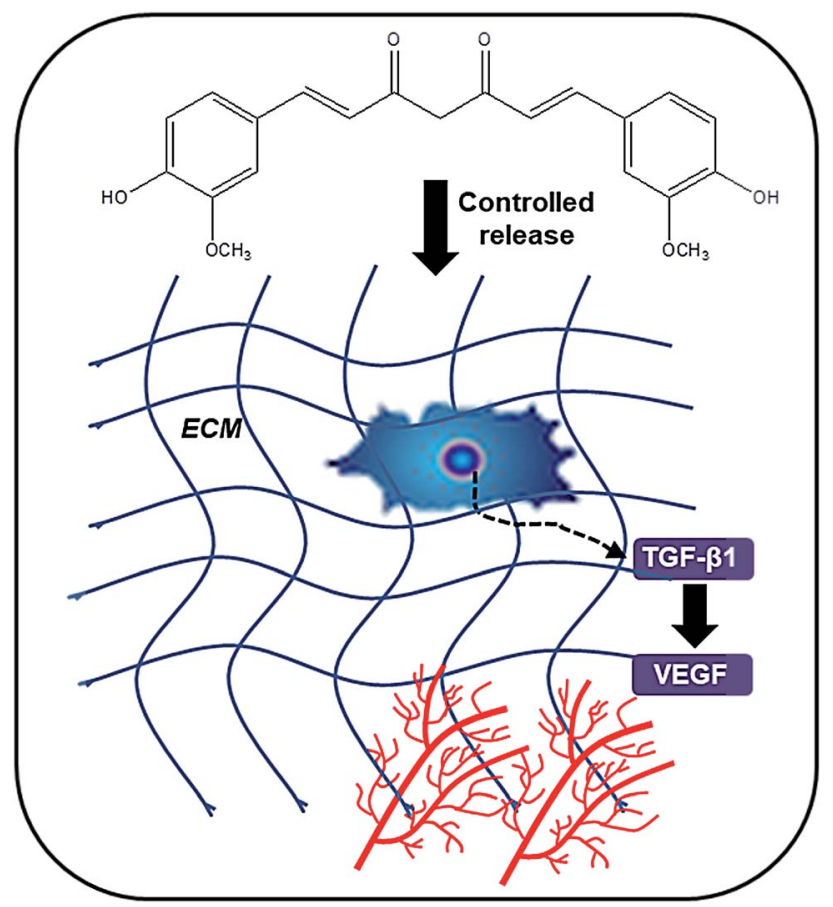

Fig. 10 Schematic representation of the mechanism of action of CUR on the promotion of angiogenesis. 


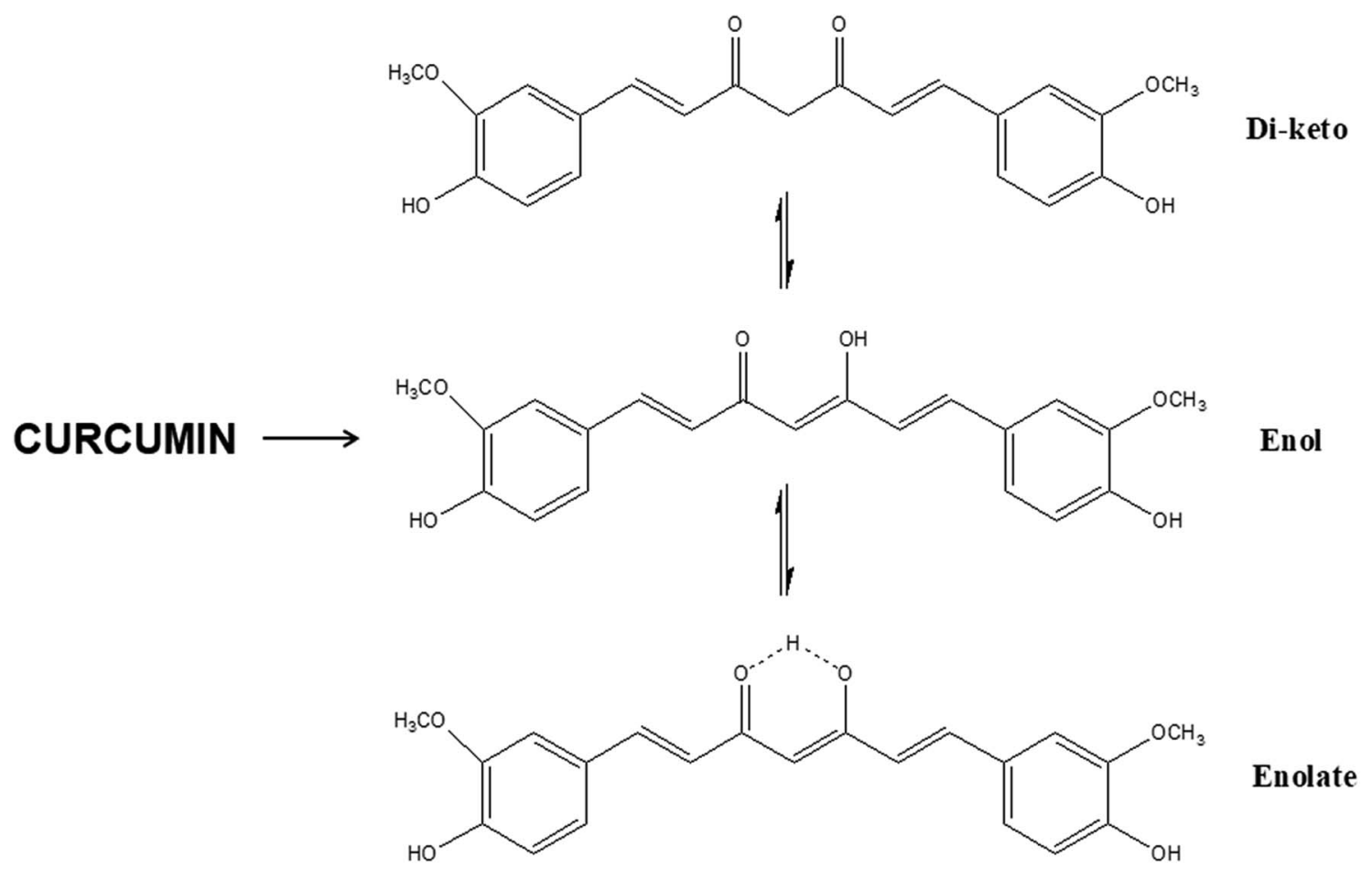

Fig. 11 Structure of curcumin in the keto-enol-enolate tautomeric forms.

significantly improve functional recovery after spinal cord injuries. Zhu et al. loaded rolipram into electrospun PLLA/PLGA mats and investigated their potential to bridge the hemisection lesion in athymic rats. ${ }^{178}$ Rolipram containing scaffolds increased axon growth, promoted angiogenesis and decreased the population of astrocytes and chondroitin sulfate proteoglycans in the lesion. In addition, locomotor scale rating analysis showed that compared to scaffolds only and sham groups, the scaffolds with rolipram significantly improved hind-limb function after 3 weeks. Furthermore, Kim et al. recently reported on two imidazole based small molecules namely neurodazine $(\mathrm{Nz})$ and neurodazole $(\mathrm{Nzl})$ as promoters of neurogenesis in pluripotent P19 cells. ${ }^{179}$ They displayed similar neurogenesis-inducing activities as RA with higher selectivity as they could suppress astrocyte differentiation unlike RA.

\subsection{Adipose TE}

CUR which has been previously reported to enhance chondrogenic differentiation was found to influence the adipogenic differentiation of hMSCs. ${ }^{180}$ When loaded into silk films, the latter significantly inhibited the proliferation of hBMSCs while promoting their adipogenic differentiation.

Pyrintegrin (Fig. 8) is a small molecule available commercially which promotes human embryonic stem cell (hESC) survival by $>30$-fold. It has been shown to be a potent promoter of adipogenesis and thus may have therapeutic potential for soft tissue reconstruction. ${ }^{181}$ Pyrintegrin treated adipose cells/ progenitors transplanted into mice, resulted in ectopic fat pads formation with morphological and functional characteristics of white adipose tissue.

Pyrintegrin-primed human ASCs seeded in 3D-bioprinted PCL scaffolds resulted in adipose tissue formation that expressed human PPAR $\gamma$, when transplanted into the dorsum of athymic mice (Fig. 9). The scaffolds when implanted in the inguinal fat pad of mice showed enhanced adipose tissue formation, suggesting pyrintegrin ability to induce in situ adipogenesis of endogenous cells. ${ }^{182}$<smiles></smiles><smiles>[InH][I-]</smiles><smiles>CC(F)(F)C1CCC(Cl)C1=O</smiles><smiles>O=C1CCCC1N1C(=O)c2ccccc2C1=O</smiles>

SC-3-149

Fig. 12 Synthesis of SC-3-149. 


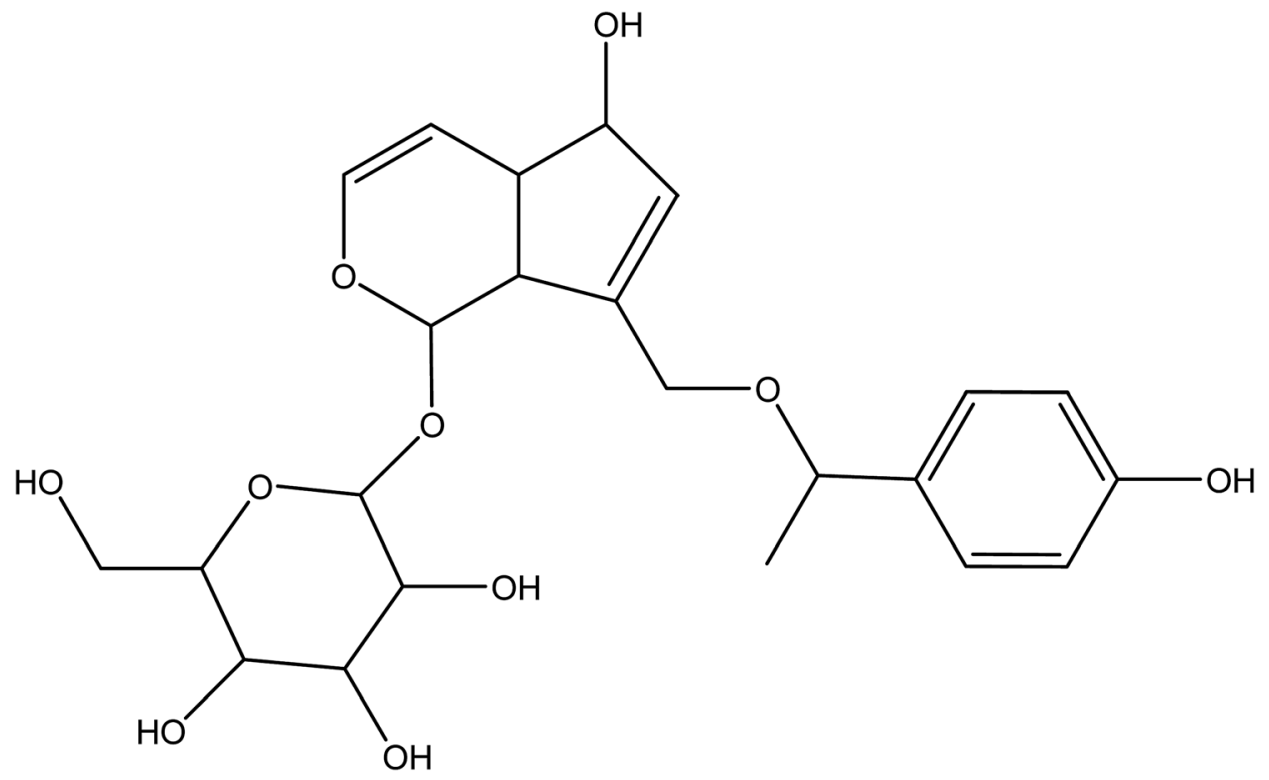

Fig. 13 Chemical structure of agnuside.

Breast reconstruction following mastectomy can potentially benefit from adipose tissue engineering where the use of scaffold promoting adipose tissue volume, have been reported. ${ }^{183,184}$ In a pre-clinical animal study on minipigs, lipoaspirate was injected in subglandular pockets pre-implanted medical grade PCL scaffolds with interconnected large pore network. Adipose tissue regeneration was observed in the animals with scaffold + lipoaspirate and scaffold only. However, the lipoaspirate group $(39.67 \% \pm 2.04)$ had higher adipose tissue regeneration than the empty control group $(8.31 \% \pm 8.94) .{ }^{185}$ This study paves the way for the loading of small molecules which can favor adipose tissue growth.

\subsection{Skin TE: angiogenesis}

One of the most important parameters for successful skin TE is good angiogenesis. A number of strategies have been explored for the promotion of angiogenesis in skin TE such as the use of nanoparticles loaded with different molecules. ${ }^{186}$ Similar strategies can be applied to scaffolds. For instance, polyvinyl alcohol/carboxymethyl cellulose (PVA/CMC) scaffolds loaded with graphene oxide nanoparticles significantly enhanced angiogenesis and arteriogenesis in chick chorioallantoic membrane model. ${ }^{187}$ CUR has been shown in a number of studies to accelerate angiogenesis in wound healing. ${ }^{188}$ Dextran hydrogel containing curcumin-loaded poly(lactide)-block-poly(ethylene glycol) nanomicelles applied to a full thickness dermal wound in $\mathrm{BALB} / \mathrm{c}$ mice, accelerated angiogenesis, fibroblast accumulation, and wound healing. Elongated blood vessels aligned in parallel were observed in the nano-CUR dextran hydrogel treatment compared to tortuous and disoriented vessels were seen in the control and the blank hydrogel groups. ${ }^{189}$ CUR enhanced the expression of TGF-beta1 and TGFbeta tIIrc which improved angiogenesis.

CUR has been co-encapsulated with EGF in PLA-10R5nanoparticles and dispersed into the thermosensitive and biocompatible PLA-10R5-PLA hydrogel. The wound healing potential of this in situ gel-forming composite (EGF-Cur-NP/H) was studied using a full-thickness incision rat model. ${ }^{190}$ The

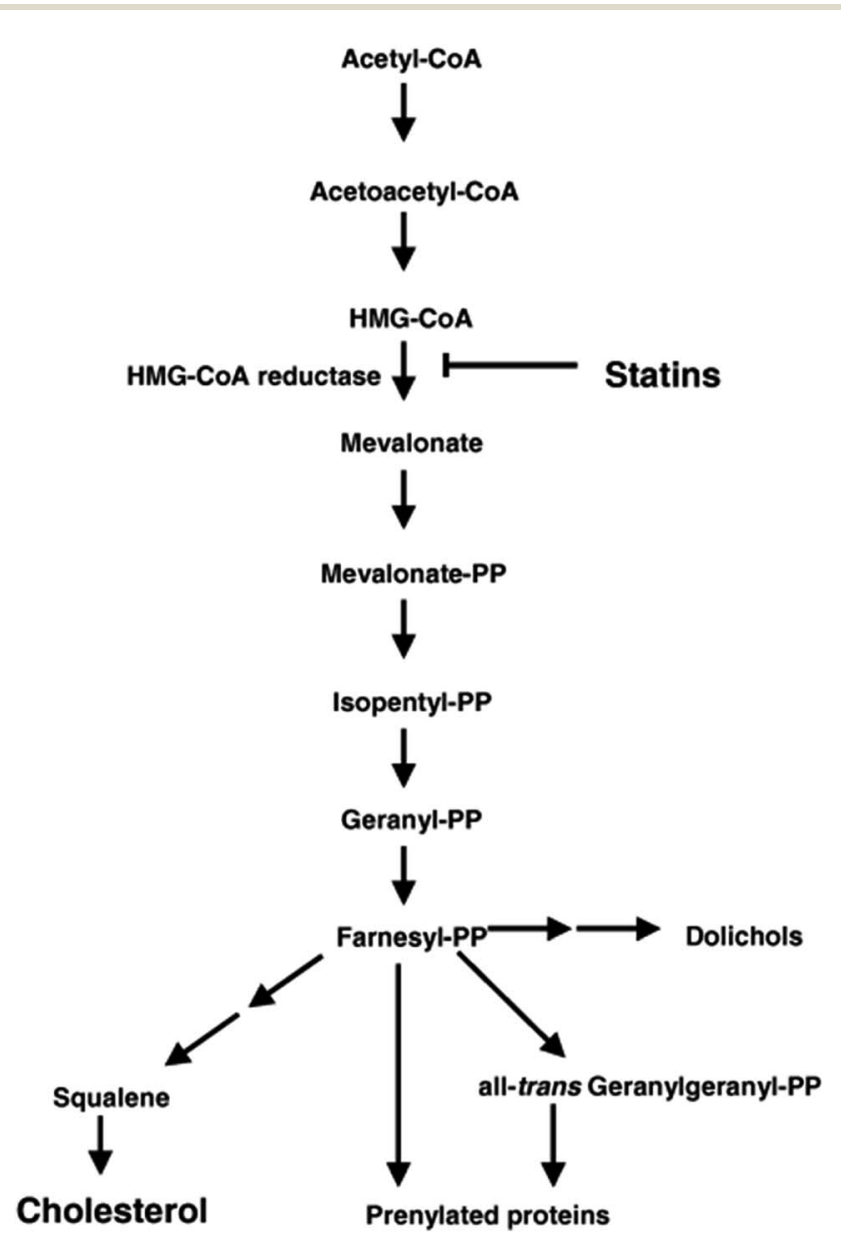

Fig. 14 Scheme showing the cholesterol lowering mechanism of simvastatin. 
Table 5 Matching GFs and small molecules

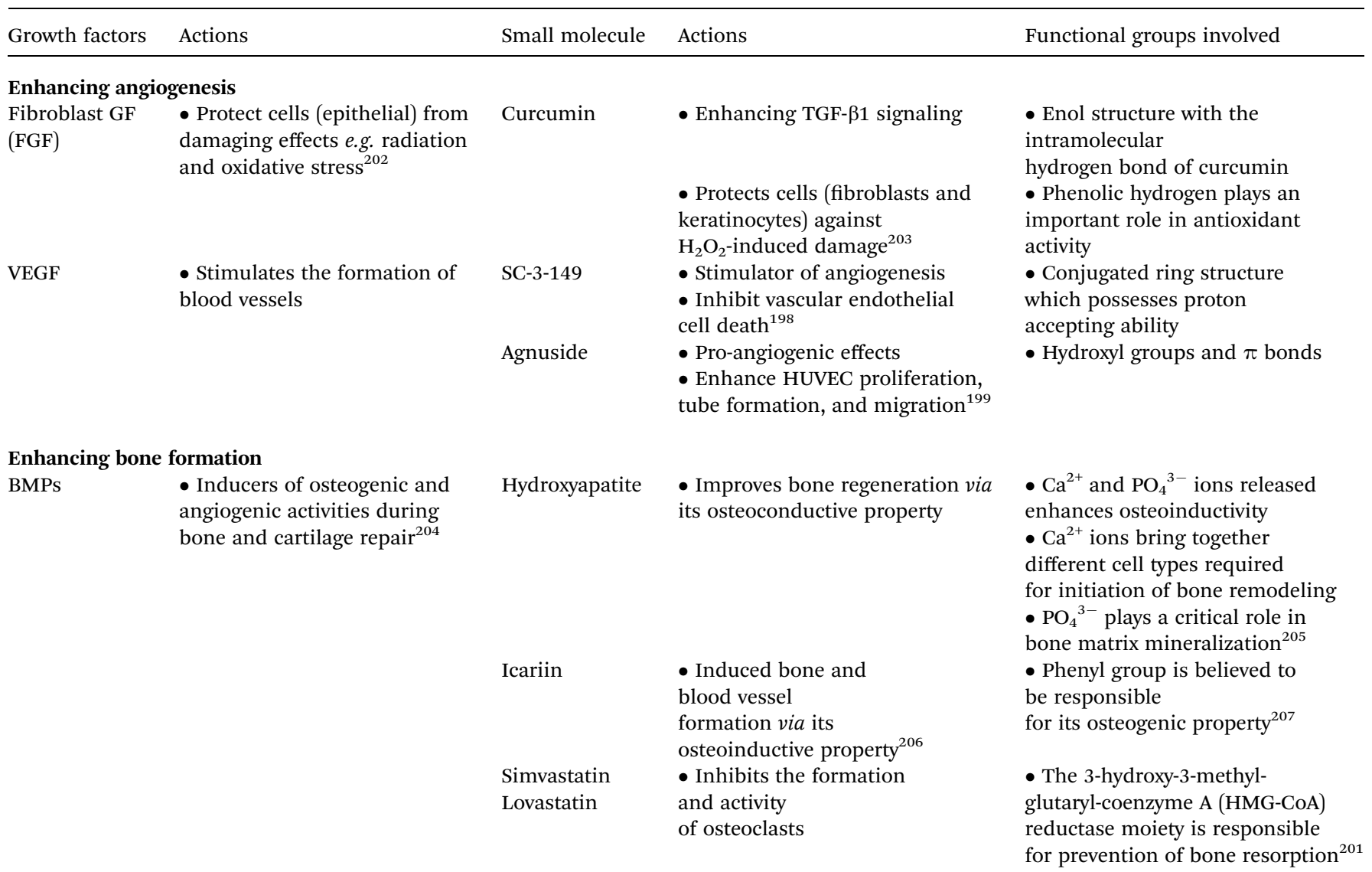

EGF-Cur-NP/H showed excellent wound healing activity via increasing granulation tissue formation, collagen deposition, and angiogenesis compared with $\mathrm{EGF}-\mathrm{NP} / \mathrm{H}$ or $\mathrm{Cur}-\mathrm{NP} / \mathrm{H}$ (Fig. 10). Curcumin could enhance the biosynthesis of TGF- $\beta 1$ which in turn enhanced angiogenesis.

Electrospun CUR-loaded PCL/gum tragacanth (GT) (PCL/GT/ Cur) used for wound healing in diabetic rats resulted in intensive angiogenesis and well-formed blood vessels with increased micro vessel density. The presence of curcumin also favored the remodeling phase as indicated by a decrease in the number of blood vessels. ${ }^{191}$

PLGA/cellulose nanocrystals composite nanofiber loaded with polyethyleneimine-carboxymethylchitosan (CMCS), pDNAangiogenin and curcumin was shown to promote angiogenesis in burn wound models in vivo. ${ }^{192}$ Angiogenin (ANG) is a stimulator of angiogenesis in skin regeneration but with low stability. Thus, polyethyleneimine-CMCS has been used to load pDNAANG and form nanoparticles which are endocytose and stimulate ANG production by cells while CUR decreased inflammatory factors IL-1 $\beta$ and IL-6.

However, theses additives have to be carefully chosen so as to have the desired effect. CUR for instance is also known for its anti-angiogenic effect inhibiting tumor progression. ${ }^{193}$ Some natural molecules such as epigallocatechin-3-gallate, a polyphenol component of green tea though it has antioxidant, immunomodulatory, photoprotective and anti-inflammatory properties, also has anti-angiogenic properties. ${ }^{194}$

\section{New perspectives: matching native GF functions with exogenous additives}

The use of exogenous additives provide the main advantages of stability and ease of fabrication compared to the direct use of GFs. Indeed, the latter's use may be limited in certain scaffoldbased applications requiring thermal processing, sterilization, or prolonged exposure to solvents. To be able to address these drawbacks, it would be very interesting and challenging to be able to match these additives with the corresponding growth factors in terms of their actions on tissue regeneration with the aim of switching GF with small molecules. This is only possible through identification of the structural unit present on the exogenous additive which makes it bioactive (Table 5). For instance, extensive research on CUR has shown that the ketoenol-enolate form of the heptadienone moiety plays a crucial role in the anti-oxidant activities of curcumin (Fig. 11). In acidic and neutral conditions the bis-keto form acts as a potent proton donor while at $\mathrm{pH}>8$, the enolate form predominates and curcumin acts as an electron donor. The presence of enolate in solution is found to be important in the radical-scavenging ability of curcumin. ${ }^{\mathbf{1 9 5}}$ For instance, acidic environment is 
known to promote angiogenesis in wounds and the use of curcumin in acidic conditions mean that it acts as a proton donor. ${ }^{196}$ Curcumin can interact with target proteins through hydrophobic interactions, including pi-pi interactions, extensive hydrogen bonding, metal chelation, and covalent bonding. ${ }^{197}$

Another reported small molecule called SC-3-149 (Fig. 12), a novel stimulator of angiogenesis, has been shown to inhibit vascular endothelial cell death owing to serum deprivation and high acidity (pH 6). ${ }^{198}$ SC-3-149 has intrinsic vasculoprotective properties comparable to VEGF and is stable to UV irradiation used for sterilization after incorporation into scaffolds. Analysis of the chemical structure of SC-3-149 shows that its ability to reduce the toxicity of locally released acidic degradation products from commonly used biomaterials in scaffolds, may be linked to its proton accepting ability and fully conjugated structure.

VEGFR2 has been shown to be able to interact via H-bonding and hydrophobic interactions with agnuside (Fig. 13), a nontoxic, natural small molecule extract of Vitex agnus-castus. ${ }^{199}$ Agnuside thus exerted pro-angiogenic effects on HUVEC proliferation, tube formation, and migration as result of its chemical structure with its numerous hydroxyl groups and $\pi$ bonds.

Simvastatin primarily used for the management of hypercholesterolaemia, is a promising scaffold additive in bone regeneration. Its chemical structure can be divided as (i) an analogue of the enzyme substrate, 3-hydroxy-3-methyl-glutarylcoenzyme A (HMG-CoA) reductase that catalyzes the conversion of HMG-CoA to mevalonate (ii) a complex hydrophobic ring structure that is covalently linked to the substrate analogue and (iii) side groups on the rings that define solubility properties (Fig. 3C) ${ }^{200}$ In its cholesterol lowering activity, it inhibits the enzyme HMG-CoA reductase by binding to it thus suppressing the synthesis of mevalonate (Fig. 14). Similarly in its bone regeneration activity, the same chemical moiety suppresses the synthesis of mevalonate and pyrophosphates, which in turn inhibit the formation and activity of osteoclast. ${ }^{201}$

\section{Conclusions}

The ultimate aim of small molecule addition to scaffolds is to promote healing by acting on the appropriate molecular pathways depending on the target tissue. Numerous molecules are being used and the trend is towards the use of natural molecules or molecules present in the body. In that category, the most successful ones are HA for bone regeneration and CUR for reduced inflammation and promotion of angiogenesis. However, there is a scarcity of data on the exact action of the multitude of additives being applied to scaffolds. More research is required into their mechanism of actions to better predict outcome and guide their efficient use. One avenue which can be explored to accelerate research in this area is the use of in silico molecular docking to compare the activity of these small molecules with GFs. The behavior of the latter when entrapped within scaffolds can be studied and then matched with small molecules susceptible to have similar actions.

\section{Conflicts of interest}

None.

\section{Abbreviations}

\begin{tabular}{|c|c|}
\hline AGG: & Aggrecan \\
\hline ANG & Angiogenin \\
\hline ATMSCs & Adipose tissue derived stem cells \\
\hline BG & Bioactive glass \\
\hline BMPs & Bone morphogenetic proteins \\
\hline BMSCs & Bone marrow stem cells \\
\hline $\mathrm{BP}$ & Bisphosphonate \\
\hline BTE & Bone tissue engineering \\
\hline cAMP & Cyclic adenosine monophosphate \\
\hline CMC & Carboxymethylchitosan \\
\hline CSPGs & Cartilage specific proteoglycans \\
\hline CUR & Curcumin \\
\hline DKK-1 & Dickkopf-1 \\
\hline ECM & Extracellular matrix \\
\hline FGF & Fibroblast growth factor \\
\hline GAG & Glycosaminoglycans \\
\hline GF & Growth factor \\
\hline GT & Gum tragacanth \\
\hline HA & Hydroxyapatite \\
\hline hADSC & Human adipose tissue-derived stromal cells \\
\hline hESC & Human embryonic stem cell \\
\hline hBMSCs & Human bone marrow stem cells \\
\hline hMSCs & Human mesenchymal stem cells \\
\hline NSCs & Neural stem cells \\
\hline $\mathrm{Nz}$ & Neurodazine \\
\hline $\mathrm{Nzl}$ & Neurodazole \\
\hline PCL & Polyaprolactone \\
\hline PHBV & Poly(hydroxybutyrate-co-valerate) \\
\hline PLA & Poly(lactic acid) \\
\hline PLGA & Poly(lactide-co-glycolide) \\
\hline PVA & Poly(vinyl alcohol) \\
\hline PU & Polyurethane \\
\hline RA & Retinoic acid \\
\hline ROS & Reactive oxygen species \\
\hline $\mathrm{SHH}$ & Sonic hedgehog \\
\hline TCP & Tricalcium phosphate \\
\hline TGF- $\beta 1$ & Transforming growth factor beta-1 \\
\hline TE & Tissue engineering \\
\hline VEGF & Vascular endothelial growth factor \\
\hline
\end{tabular}

\section{Acknowledgements}

The authors thank the Mauritius Research Council and the Tertiary Education Commission for funding the Biomaterials, Drug Delivery and Nanotechnology Unit.

\section{References}

1 K. A. Kilian, B. Bugarija, B. T. Lahn and M. Mrksich, Proc. Natl. Acad. Sci. U. S. A., 2010, 107, 4872. 
2 C. J. Bettinger, R. Langer and J. T. Borenstein, Angew. Chem., Int. Ed. Engl., 2009, 48, 5406.

3 D. S. Benoit, M. P. Schwartz, A. R. Durney and K. S. Anseth, Nat. Mater., 2008, 7, 816.

4 X. Liu, J. He, S. Zhang, X. M. Wang, H. Y. Liu and F. Z. Cui, J. Tissue Eng. Regen. Med., 2013, 7(2), 112.

5 P. Murray, K. Vasilev, M. C. Fuente, E. Ranghini, H. Tensaout, A. Rak-Raszewska, B. Wilm, D. Edgar, R. D. Short and S. E. Kenny, Biochem. Soc. Trans., 2010, 38, 1062.

6 Y. J. Ren, H. Zhang, H. Huang, X. M. Wang, Z. Y. Zhou, F. Z. Cui and Y. H. An, Biomaterials, 2009, 30, 1036.

7 R. Ayala, C. Zhang, D. Yang, Y. Hwang, A. Aung, S. S. Shroff, F. T. Arce, R. Lal, G. Arya and S. Varghese, Biomaterials, 2011, 32, 3700 .

8 T. Boontheekul, E. E. Hill, H. J. Kong and D. J. Mooney, Tissue Eng., 2007, 13, 1431.

9 L. Ghasemi-Mobarakeh, M. P. Prabhakaran, L. Tian, E. Shamirzaei-Jeshvaghani, L. Dehghani and S. Ramakrsihna, World J. Stem Cells, 2015, 7(4), 728.

10 C. Zhao, A. Tan, G. Pastorin and H. K. Ho, Biotechnol. Adv., 2013, 31(5), 654.

11 L. Krishna, K. Dhamodaran, C. Jayadev, K. Chatterjee, R. Shetty, S. S. Khora and D. Das, Stem Cell Res. Ther., 2016, 7, 188.

12 K. E. Hammerick, Z. Huang, N. Sun, M. T. Lam, F. B. Prinz, J. C. Wu, G. W. Commons and M. T. Longaker, Tissue Eng., Part A, 2011, 17, 495.

13 Z. Melkoumian, J. L. Weber, D. M. Weber, A. G. Fadeev, Y. Zhou, P. Dolley-Sonneville, J. Yang, L. Qiu, C. A. Priest, C. Shogbon, A. W. Martin, J. Nelson, P. West, J. P. Beltzer, S. Pal and R. Brandenberger, Nat. Biotechnol., 2010, 28, 606.

14 M. Archetti, Evol. Appl., 2013, 6(8), 1146.

15 A. Aravamudhan, D. M. Ramos, J. Nip, A. Subramanian, R. James, M. D. Harmon, X. Yu and S. G. Kumbar, Curr. Pharm. Des., 2013, 19, 3420.

16 K. W. Lo, K. M. Ashe, H. M. Kan and C. T. Laurencin, Regener. Med., 2012, 7, 535.

17 K. Lee, E. A. Silva and D. J. Mooney, J. R. Soc., Interface, 2010, 8(55), 1742.

18 L. Lamalice, F. Le Bœuf and J. Huot, Circ. Res., 2007, 100, 782.

19 K. Lee, E. A Silva and D. J. Mooney, J. R. Soc., Interface, 2010, 8(55), 1742.

20 D. M. Ornitz and N. Itoh, Genome Biol., 2001, 2(3), reviews3005.

21 Y. R. Yun, J. E. Won, E. Jeon, S. Lee, W. Kang, H. Jo, J. H. Jang, U. S. Shin and H. W. Kim, J. Tissue Eng., 2010, 218142.

22 H. Uchi, A. Igarashi, K. Urabe, T. Koga, J. Nakayama, R. Kawamori, K. Tamaki, H. Kirakata, T. Ohura and M. Furue, Eur. J. Dermatol., 2009, 19(5), 461.

23 S. Cai, Y. Liu, X. Zhwng Shu and G. D. Prestwich, Biomaterials, 2005, 26(30), 6054.

24 D. Chen, M. Zhao and G. R. Mundy, Growth Factors, 2004, 22, 233.
25 N. Sykaras and L. A. Opperman, J. Oral Sci., 2003, 45(2), 5773.

26 B. Shen, D. Bhargav, A. Wei, L. A. Williams, H. Tao, D. D. Ma and A. D. Diwan, Int. J. Biol. Sci., 2009, 5(2), 192.

27 A. C. Carreira, F. H. Lojudice, E. Halcsik, R. D. Navarro, M. C. Sogayar and J. M. Grajeiro, J. Dent. Res., 2014, 93, 335.

28 S. Ehnert, J. Zhao, S. Pscheerer, T. Freude, S. Dooley, A. Kolk, U. Stoeckle, A. K. Nussler and R. Hube, $B M C$ Med., 2012, 10, 101.

29 S. D. Rodgers, B. J. Marascalchi, B. T. Grobelny, M. L. Smith and U. Samadani, J. Neurosurg. Spine, 2013, 18, 582.

30 D. G. Crandall, J. Revella, J. Patterson, E. Huish, M. Chang and R. McLemore, Spine, 2013, 38, 1128.

31 R. Fu, S. Selph, M. McDonagh, K. Peterson, A. Tiwari, R. Chou and M. Helfand, Ann. Intern. Med., 2013, 158, 890.

32 B. Moatz and P. J. Tortolani, Surg. Neurol. Int., 2013, 4, S67S73.

33 E. J. Carragee, E. L. Hurwitz and B. K. Weiner, Spine J., 2011, 11(6), 471.

34 K. E. Johnson and T. A. Wilgus, Adv. Wound Care, 2014, 3(10), 647.

35 N. Ferrara, Endocr. Rev., 2004, 25(4), 581.

36 Y. D. Lin, C. Y. Luo, Y. N. Hu, M. L. Yeh, Y. C. Hsueh, M. Y. Chang, D. C. Tsai, J. N. Wang, M. J. Tang, E. I. H. Wei, M. L. Springer and P. C. H. Hsieh, Sci. Transl. Med., 2012, 4(146), $146 \mathrm{ra109.}$

37 C. H. Heldin and B. Westermark, Cell Regul., 1990, 1(8), 555.

38 C. H. Heldin, A. Johnsson, S. Wennergren, C. Wernstedt, C. Betsholtz and B. Westermark, Nature, 1986, 319, 511.

39 E. Canalis, T. McCarthy and M. Centrella, J. Clin. Invest., 1988, 81, 277.

40 R. A. Seifert, C. E. Hart, P. E. Phillips, J. W. Forstrom, R. Ross, M. J. Murray and D. F. Bowen- Pope, J. Biol. Chem., 1989, 264, 8771.

41 P. Shah, L. Keppler and J. Rutkowki, J. Oral Implantol., 2014, 40(3), 330-340.

42 R. Ross, N. Engl. J. Med., 1986, 314, 488.

43 K. Lee, E. A. Silva and D. J. Mooney, J. R. Soc., Interface, 2011, 8(55), 153.

44 H. G. Schomoekel, F. E. Weber, J. C. Schense, K. W. Grätz, P. Schawalder and J. A. Hubbell, Biotechnol. Bioeng., 2005, 89(3), 253.

45 Y. Ito, Soft Matter, 2008, 4, 46.

46 F. G. Rocha, C. A. Sundback, N. J. Krebs, J. K. Leach, D. J. Mooney, S. W. Ashley, J. P. Vacanti and E. E. Whang, Biomaterials, 2008, 29(19), 2884.

47 T. P. Richardson, M. C. Peters, A. B. Ennett and D. J. Mooney, Nat. Biotechnol., 2001, 19(11), 1029.

48 T. M. DeWitte, L. E. Fratila-Apachitei, A. A. Zadpoor and N. A. Peppas, Regener. Biomater., 2018, 5(4), 197.

49 Y. Yoo, H. Hyun, S. J. Yoon, S. Y. Kim, D. W. Lee, S. Um, S. O. Hong and D. H. Yang, J. Ind. Eng. Chem., 2018, 67, 365.

50 G. Cheng, X. Ma, J. Li, Y. Cheng, Y. Cao, Z. Wang, X. Shi, Y. Du, H. Deng and Z. Li, Int. J. Pharm., 2018, 547(1-2), 656.

51 F. M. Chen, M. Zhang and Z. F. Wu, Biomaterials, 2010, 31(24), 6279. 
52 B. H. Walpoth, P. Zammaretti, M. Cikiricioglu, E. Khabiri, M. K. Djebaili, J. C. Pache, J. C. Tille, Y. Aggoun, D. Morel, A. Kalangos, J. A. Hubbell and A. H. Zisch, J. Thorac. Cardiovasc. Surg., 2007, 133(5), 1163.

53 H. Kawaguchi, H. Oka, S. Jingushi, T. Izumi, M. Fukunaga, K. Sato, T. Matsushita and K. Nakamura, J. Bone Miner. Res., 2010, 25(12), 2735.

54 W. Petersen, T. Pufe, C. Stärke, T. Fuchs, S. Kopf, W. Neumann, T. Zantop, J. Paletta, M. Raschke and R. Becker, Arch. Orthop. Trauma Surg., 2007, 127(4), 235.

55 M. P. Baker and F. Carr, Curr. Drug Saf., 2010, 5, 308.

56 H. Egusa, M. Saeki, M. Doi, S. Fukuyasu, Y. Kamisaki and H. Yatani, J. Oral Biosci., 2010, 52, 107.

57 C. E. Segar, E. M. Ogle and A. E. Edward, Curr. Pharm. Des., 2013, 19(19), 3403.

58 G. Blaich, B. Janssen, G. Roth and J. Salfeld, Overview: Differentiating Issues in the Development of Macromolecules Compared with Small Molecules, Handbook of Pharmaceutical Biotechnology, John Wiley \& Sons, Inc., Hoboken, NJ, USA, 2006, pp. 89-123, DOI: 10.1002/9780470117118.ch1c.

59 K. Fu, A. M. Klibanov and R. Langer, Protein stability in controlled-release systems, Nat. Biotechnol., 2000, 18, 24.

60 K. W. Lo, B. D. Ulery, M. Deng, K. M. Ashe and C. T. Laurencin, Recent Pat. Biomed. Eng., 2011, 4, 153.

61 J. C. Crokett, M. J. Rogers, F. P. Coxon, L. J. Hocking and M. H. Helfrich, J. Cell Sci., 2011, 124, 991.

62 S. Bose, M. Roy and A. Bandyopadhyay, Trends Biotechnol., 2012, 30, 546.

63 J. H. Song, J. H. Kim, S. Park, W. Kang, H. W. Kim, H. E. Kim and J. H. Jang, J. Bone Miner. Metab., 2008, 26, 138.

64 W. F. Zambuzzi, C. V. Ferreira, J. M. Granjeiro and H. Aoyama, J. Biomed. Mater. Res., Part A, 2011, 97, 193.

65 J. A. Mandell, D. R. Carter, S. B. Goodman, D. J. Schurman and G. S. Beaupre, Clin. Biomech., 2004, 19, 695.

66 N. A. Ramaniraka, L. R. Rakotomanana and P. F. Leyraz, J. Bone Jt. Surg., Br. Vol., 2000, 82, 297.

67 M. Nepal, L. Li, T. S. Bae, B. I. Kim and Y. Soh, Biomol. Ther., 2014, 22(6), 563.

68 J. Abtahi, P. Tengvall and P. Aspenberg, Int. J. Oral Maxillofac. Surg., 2010, 39(7), 673.

69 M. N. Rahaman, D. E. Ray, B. S. Bal, Q. Fu, S. B. Jung, L. F. Bonewald and A. P. Tomsia, Acta Biomater., 2011, $7(6), 2355$.

70 K. Ishikawa, Y. Miyamoto, A. Tsuchiya, K. Hayashi, K. Tsuru and G. Ohe, Materials, 2018, 11(10), 1993.

71 K. Ishikawa, Y. Miyamoto, A. Tsuchiya, K. Hayashi, K. Tsuru and G. Ohe, Materials, 2018, 11(10), 1993.

72 V. M. Anghelescu, I. Neculae, O. Dinca, C. Vladan, C. Socoliuc, M. Cioplea, L. Nichita, C. Popp, S. Zurac and A. Bucur, J. Immunol. Res., 2018, 2018, 9349207.

73 L. Xia, Z. Yin, L. Mao, X. Wang, J. Liu, X. Jiang, Z. Zhang, K. Lin, J. Chang and B. Fang, Sci. Rep., 2016, 6, 22005.

74 A. B. Lovati, S. Lopa, C. Recordati, G. Talo, C. Turrisi, M. Bottagisio, M. Losa, E. Scanziani and M. Moretti, Calcif. Tissue Int., 2016, 99(2), 209.
75 H. Liu, H. Peng, Y. Wu, C. Zhang, Y. Cai, G. Xu, Q. Li, X. Chen, J. Ji, Y. Zhang and H. W. OuYang, Biomaterials, 2013, 34, 4404.

76 A. Thorfve, C. Lindahl, W. Xia, K. Igawa, A. Lindahl, P. Thomsen, A. Palmquist and P. Tengvell, Acta Biomater., 2014, 10, 1451.

77 X. Lu, J. Wang, B. Li, Z. Zhang and L. Zhao, J. Biomed. Mater. Res., Part A, 2014, 102, 2833.

78 V. S. Kattimani, S. P. Chakravarthi, K. N. N. Devi, M. S. Sridhar and L. K. Prasad, Indian J. Dent. Res., 2014, 25(5), 594.

79 T. Bizemjima, T. Takeuchi, F. Seshima and A. Saito, Clin. Oral Implants Res., 2016, 27(11), 1360.

80 M. Nepal, L. Li, T. S. Bae, B. I. Kim and Y. Soh, Biomol. Ther., 2014, 22(6), 563.

81 J. Abtahi, P. Tengvall and P. Aspenberg, Int. J. Oral Maxillofac. Surg., 2010, 39(7), 673.

82 M. Shahnazari, W. Yao, W. W. Dai, B. Wang, S. S. IonovaMartin, R. O. Ritchie, D. Heeren, A. J. Burghardt, D. P. Nicolella, M. G. Kimiecik and N. E. Lane, Bone, 2010, 46, 1267.

83 D. E. Hughes, K. R. Wright, H. L. Uy, A. Sasaki, T. Yoneda, G. D. Roodman, G. R. Mundy and B. F. Boyce, J. Bone Miner. Res., 1995, 10(10), 1478.

84 V. Viereck, G. Emons, V. Lauck, K. H. Frisch, S. Blacheke, C. Grundker and L. C. Hofbauer, Biochem. Biophys. Res. Commun., 2002, 291(3), 680.

85 W. Liu, T. Wang, X. Zhao, X. Dan, W. W. Lu and H. Pan, Bioact. Mater., 2016, 1(2), 151.

86 W. Gong, Y. Dong, S. Wang, X. Gao and X. Chen, RSC Adv., 2017, 7, 13760.

87 S. Midha, T. B. Kim, W. Van Den Bergh, P. D. Lee, J. R. Jones and C. A. Mitchell, Acta Biomater., 2013, 9(11), 9169.

88 F. Baino, G. Novajra and C. Vitale-Brovarone, Front. Bioeng. Biotechnol., 2015, 3, 202.

89 A. R. Boccaccini, Ceramics, in Biomaterials, Artificial Organs and Tissue Engineering, Woodhead Publishing Series in Biomaterials, 2005, p. 26.

90 G. Wei and P. X. Ma, Biomaterials, 2004, 25(19), 4749.

91 A. López-Noriega, E. Quinlan, N. Celikkin and F. J. O'Brien, APL Mater., 2015, 3, 014910.

92 O. Guillaume, M. A. Geven, C. M. Sprecher, V. A. Stadelmann, D. W. Grijpma, T. T. Tang, L. Qin, Y. Lai, M. Alini, J. D. de Bruijn, H. Yuan, R. G. Richards and D. Eglin, Acta Biomater., 2017, 54, 386.

93 M. G. Flores-Sanchez, A. M. Raya-Rivera, D. R. EsquilianoRendon, P. G. Ontiveros-Nevares, N. C. Islas-Arteaga, J. Morales-Corona and R. Olayo, Int. J. Polym. Mater. Polym. Biomater., 2018, 67(7), 427.

94 G. Mundy, R. Garrett, S. Harris, J. Chan, D. Chen, G. Rossini, B. Boyce, M. Zhao and G. Gutierrez, Science, 1999, 286, 1946.

95 M. Schachter, Fundam. Clin. Pharmacol., 2005, 19, 117.

96 T. Yoshii, A. E. Hafeman, J. S. Nyman, J. M. Esparza, K. Shinomiya, D. M. Spengler, G. R. Mundy, G. E. Gutierrez and S. A. Guelcher, Tissue Eng., Part A, 2010, 16(7), 2369. 
97 M. Monjo, M. Rubert, J. C. Wohlfahrt, H. J. Ronold, J. E. Ellingsen and S. P. Lyngstadaas, Acta Biomater., 2010, 6, 1405.

98 R. Wadagaki, D. Mizuno, A. Yamawaki-Ogata, M. Satake, H. Kaneko, S. Hagiwara, N. Yamamoto, Y. Narita, H. Hibi and M. Ueda, Ann. Biomed. Eng., 2011, 39, 1872.

99 H. Yin, Y. G. Li, M. Si and J. M. Li, J. Biomed. Mater. Res., 2012, 100(11), 2991.

100 I. C. Tai, Y. C. Fu, C. K. Wang, J. K. Chang and M. L. Ho, Int. J. Nanomed., 2013, 8, 3895.

101 E. Bonnelye, A. Chabadel, F. Saitel and P. Jurdic, Bone, 2008, 42(1), 129.

102 P. J. Marie, Curr. Opin. Rheumatol., 2006, 18(suppl 1), S11S15.

103 J. Kokesch-Himmelreich, M. Schumacher, M. Rohnke, M. Gelinsky and J. Janek, Biointerphases, 2013, 8, 17.

104 S. Jebahi, H. Oudadesse, H. El Feki, T. Rebai, H. Kesbes, P. Pellen and A. El Feki, J. Appl. Biomed., 2012, 10(4), 195.

105 D. A. Barrio and S. B. Etcheverry, Can. J. Physiol. Pharmacol., 2006, 84(7), 677.

106 A. M. Cortizo, M. S. Molinuevo, D. A. Barrio and L. Bruzzone, Int. J. Biochem. Cell Biol., 2006, 38, 1171.

107 B. Saxena, J. Saxena, R. Nema, D. Singh and A. Gupta, J. Pharmacogn. Phytochem., 2013, 1(6), 2349.

108 P. Rathee, H. Chaudhary, S. Rathee, D. Rathee, V. Kumar and K. Kohli, Inflammation Allergy: Drug Targets, 2009, 8, 229.

109 L. Leotoing, M. J. Davicco, P. Lebecque, Y. Wittrant and V. Coxam, Mol. Nutr. Food Res., 2014, 58, 1239.

110 D. Zhang, J. Zhang, C. Fong, X. Yao and M. Yang, Biochimie, 2012, 94, 2514.

111 S. Srivastva, R. Bankar and P. Roy, Phytomedicine, 2013, 20, 683.

112 L. Song, J. Zhao, X. Zhang, H. Li and Y. Zhou, Eur. J. Pharmacol., 2013, 714, 15.

113 J. F. Zhang, C. Y. Chan, C. L. Meng, M. C. Lin, Y. C. Chen, M. L. He, P. C. Leung and H. F. Kung, Mol. Cell. Endocrinol., 2010, 314, 70.

114 D. Zheng, S. Peng, S. H. Yang, Z. W. Shao, C. Yang, Y. Feng, W. Wu and W. X. Zhen, Bone, 2012, 51(1), 85.

115 M. Li, N. D. Zhang, Y. Wang, T. Han, Y. P. Jiang, K. Rahman, L. P. Qin, H. L. Xin and Q. Y. Zhang, J. Ethnopharmacol., 2016, 185, 120.

116 J. Zhang, Y. Li, J. Sun, C. Liu and D. Zhang, Biol. Trace Elem. Res., 2011, 143(3), 1746.

117 T. Wu, K. H. Nan, J. D. Chen, D. Jin, S. Jiang, P. R. Zhao, J. C. Xu, H. Du, X. Q. Zhang, J. W. Li and G. X. Pei, Chin. Sci. Bull., 2009, 54, 2953.

118 K. M. Chen, H. P. Ma, B. F. Ge, X. Y. Liu, L. P. Ma, M. H. Bai and Y. Wang, Pharmazie, 2007, 62, 785-789.

119 B. H. Chung, J. D. Kim, C. K. Kim, J. H. Kim, M. H. Won, H. S. Lee, M. S. Dong, K. S. Ha, Y. G. Kwon and Y. M. Kim, Biochem. Biophys. Res. Commun., 2008, 376, 404.

120 M. Mizutani, K. Ikeda, Y. Kawai and Y. Yamori, Biochem. Biophys. Res. Commun., 1998, 253, 859.
121 C. R. Dosier, C. P. Erdman, J. H. Park, Z. Schwartz, B. D. Boyan and R. E. Gulberg, J. Mech. Behav. Biomed. Mater., 2012, 11, 112.

122 H. Zhou, L. Shang, X. Li, X. Zhang, G. Gao, C. Guo, B. Chen, Q. Liu, Y. Gong and C. Shao, Exp. Cell Res., 2009, 315, 2953.

123 L. Peltz, J. Goemz, M. Marquez, F. Alencastro, N. Atashpanjeh, T. Quang, T. Bach and Y. Zhao, PLoS One, 2012, 7, e37162.

124 Y. Li, S. Danmark, U. Edlund, A. Finne-Wistrand, X. He, M. Norgard, E. Blomen, K. Hultenby, G. Andersson and U. Lindgren, Acta Biomater., 2011, 7, 751.

125 G. K. Gupta, A. Kumar, V. Khedgikar, J. Gautam, G. K. Nagar, V. Gupta, A. Verma, A. K. Dwivedi, A. Misra, R. Trivedi and P. R. Mishra, Nanomedicine, 2013, 8(5), 757.

126 J. S. Lee, J. S. Lee, M. S. Lee, S. An, K. Yang, K. Lee, H. S. Yang, H. Lee and S. W. Cho, Chem. Mater., 2017, 29(10), 4375.

127 D. Xue, E. Chen, W. Zhang, X. Gao, S. Wang, Q. Zheng, Z. Pan, H. Li and L. Liu, Oncotarget, 2017, 8, 21031.

128 K. Y. Chen, K. C. Lin, Y. S. Chen and C. H. Yao, Evid. Based Complement. Alternat. Med., 2013, 2013, 283941.

129 Y. Ji, L. Wang, D. C. Watts, H. Qiu, T. You, F. Deng and X. Wu, Dent. Mater., 2014, 30(11), 1263.

130 Y. J. Kim, Y. C. Bae, K. T. Suh and J. S. Jung, Biochem. Pharmacol., 2006, 72(10), 1268.

131 M. Notoya, Y. Tsukamoto, H. Nishimura, J. T. Woo, K. Nagai, I. S. Lee and H. Hagiwara, Eur. J. Pharmacol., 2004, 485(1-3), 89.

132 T. Goto, K. Hagiwara, N. Shirai, K. Yoshida and H. Hagiwara, Cytotechnology, 201, 67(2), 357.

133 C. Prouillet, J. C. Maziere, C. Maziere, A. Wattel, M. Brazier and S. Kamel, Biochem. Pharmacol., 2004, 6, 1307.

134 R. W. K. Wong and A. B. M. Rabie, J. Orthop. Res., 2008, 2, 1061.

135 M. Notoya, Y. Tsukamoto, H. Nishimura, J. T. Woo, K. Nagai, I. S. Lee and H. Hagiwara, Eur. J. Pharmacol., 2004, 485(1-3), 89.

136 X. Ying, L. Sun, X. Chen, H. Zu, X. Guo, H. Chen, J. Hong, S. Cheng and L. Peng, Eur. J. Pharmacol., 2013, 721, 225.

137 Y. H. Gao and M. Yamaguchi, Biol. Pharm. Bull., 1999, 22, 805.

138 D. Xue, E. Chen, W. Zhang, X. Gao, S. Wang, Q. Zheng, Z. Pan, H. Li and L. Liu, Oncotarget, 2017, 8, 21031.

139 A. Trzeciakiewicz, V. Habauzit, S. Mercier, P. Lebecque, M. J. Davicco, V. Coxam, C. Demigne and M. N. Horcajada, J. Nutr. Biochem., 2010, 21(5), 424.

140 B. Bhargavan, A. K. Gautam, D. Singh, A. Kumar, S. Chaurasia, A. M. Tyagi, D. K. Yadav, J. S. Mishra, A. B. Singh, S. Sanyal, A. Goel, R. Maurya and N. Chattopadhyay, J. Cell. Biochem., 2009, 10, 388.

141 T. Tominari, M. Hirata, C. Matsumoto, M. Inada and C. Miyaura, J. Pharmacol. Sci., 2012, 119, 390.

142 Y. L. Hsu, H. L. Lin, C. H. Hung and P. L. Kuo, Mol. Nutr. Food Res., 2009, 53, 1452.

143 S. Qin, W. Zhou, S. Liu, P. Chen and H. Wu, Int. J. Clin. Exp. Med., 2015, 8(5), 7125. 
144 H. P. Ma, X. N. Ma, B. F. Ge, P. Zhen, J. Zhou, Y. H. Gao, C. J. Xian and K. M. Chen, Cell Proliferation, 2014, 47, 527. 145 H. Liu, Y. Xiong, X. Zhu, H. Gao, S. Yin, J. Wang, G. Chen, C. Wang, L. Xiang, P. Wang, J. Fang, R. Zhang and L. Yang, Exp. Ther. Med., 2017, 13(4), 1360.

146 X. Wu, J. Walker, J. Zhang, S. Ding and P. G. Schultz, Chem. Biol., 2004, 11, 1229.

147 T. S. Pereira, R. Almeida-Palmas, P. S. Gomes and M. H. Fernandes, Bone, 2009, 44(suppl. 2), S314.

148 K. Gellynck, R. Shah, M. Parkar, A. Young, P. Buxton and P. Brett, Bone, 2013, 57(2), 405.

149 Y. Q. Yang, Y. Y. Tan, R. Wong, A. Wenden, L. K. Zhang and A. B. Rabie, Int. J. Oral Sci., 2012, 4(2), 64.

150 S. Young, Z. S. Patel, J. D. Kretlow, M. B. Murphy, P. M. Mountziaris, L. S. Baggett, H. Ueda, Y. Tabata, J. A. Jansen, M. Wong and A. G. Mikos, Tissue Eng., Part A, 2009, 15, 2347.

151 X. Yu, A. Khalil, P. N. Dang, E. Alsberg and W. L. Murphy, Adv. Funct. Mater., 2014, 24, 3082.

152 C. E. P. Aronin, L. S. Sefcik, S. S. Tholpady, A. Tholpady, K. W. Sadik, T. L. Macdonald, S. M. Peirce, B. R. Wamhoff, K. R. Lynch, R. C. Ogle and E. A. Botchwey, Tissue Eng., Part A, 2010, 16, 1801.

153 A. Heilmann, T. Schinke, R. Bindl, T. Wehner, A. Rapp, M. Haffner-Luntzer, A. Liedert, M. Amling and A. Ignatius, J. Orthop. Res., 2013, 31, 1845.

154 T. Maeda, T. Kawane and N. Horiuchi, Endocrinology, 2003, 144, 681.

155 H. Pullisaar, J. E. Reseland, H. J. Haugen, J. E. Brinchmann and E. Ostrup, Biochem. Biophys. Res. Commun., 2014, 447, 139.

156 J. E. Rosselli, D. M. Martins, J. L. Martins, C. R. Oliveira, D. J. Fagundes and M. O. Taha, Acta Cir. Bras., 2014, 29, 87.

157 H. Yin, Y. G. Li, M. Si and J. M. Li, J. Biomed. Mater. Res., Part A, 2012, 100, 2991.

158 S. Chen, J. Y. Yang, S. Y. Zhang, L. Feng and J. Ren, Chin. Med. J., 2011, 124(23), 3953.

159 J. Wu, J. Sun and J. Liu, Appl. Surf. Sci., 2014, 317, 278.

160 D. Li, T. Yuan, X. Zhang, Y. Xiao, R. Wang, Y. Fan and X. Zhang, Osteoarthritis Cartilage, 2012, 20(12), 1647.

161 Z. Wang, K. Li, H. Sun, J. Wang, Z. Fu and M. Liu, Mol. Med. Rep., 2018, $17(6), 8237$.

162 S. Shishodia, T. Singh and M. M. Chaturvedi, Adv. Exp. Med. Biol., 2007, 595, 127.

163 C. Buhrmann, A. Mobasheri, U. Matis and M. Shakibaei, Arthritis Res. Ther., 2010, 12(4), R127.

164 C. Csaki, A. Mobasheri and M. Shakibaei, Arthritis Res. Ther., 2009, 11(6), R165.

165 Y. Henrotin, A. L. Clutterbuck, D. Allway, E. M. Lodwig, P. Harris, M. Mathy-Hartert, M. Shakibaei and A. Mobasheri, Osteoarthritis Cartilage, 2010, 18, 141.

166 D. K. Kim, J. I. Kim, B. R. Sim and G. Khang, Mater. Sci. Eng., C, 2017, 78, 571.

167 J. Wu, K. Xue, H. Li, J. Sun and K. Liu, PLoS One, 2013, 8(8), e71563.

168 M. Centola, F. Abbruzzese, C. Scotti, A. Barbero, G. Vadalà, V. Denaro, I. Martin, M. Trombetta, A. Rainer and
A. Marsano, Tissue Eng., Part A, 2013, 19, 17-18, DOI: 10.1089/ten.tea.2012.0455.

169 Y. Henrotin, A. Labasse, S. X. Zheng, P. Galais, Y. Tsouderos, J. M. Crielarrd and J. Y. Reginster, J. Bone Miner. Res., 2001, 16, 299.

170 D. G. Yu, H. F. Ding, Y. Q. Mao, M. Liu, B. Yu, X. Zhao, X. Q. Wang, Y. Li, G. W. Liu, S. B. Nie, S. Liu and Z. A. Zhu, Acta Pharmacol. Sin., 2013, 34(3), 393.

171 B. T. Tan, L. Wang, S. Li, Z. Y. Long, Y. M. Wu and Y. Liu, Int. J. Clin. Exp. Pathol., 2015, 8(7), 8129.

172 X. J. Li, B. Y. Hu, S. A. Jones, Y. S. Zhang, T. LaVaute, Z. W. Du and S. C. Zhang, Stem Cells, 2008, 26(4), 886.

173 L. Binan, C. Tendey, G. De Crescenczo, R. El Ayoubi, A. Ajji and M. Jolicoeur, Biomaterials, 2014, 35(2), 664.

174 D. D. Pearse, F. C. Pereira, A. E. Marcillo, M. L. Bates, Y. A. Berrocal, M. T. Filbin and M. B. Bunge, Nat. Med., 2004, 10(6), 610.

175 C. A. Iannotti, M. Clark, K. P. Horn, N. van Rooijen, J. Silver and M. P. Steinmetz, Exp. Neurol., 2011, 230, 3.

176 C. M. Whitaker, E. Beaumont, M. J. Wells, D. S. Magnuson, M. Hetman and S. M. Onifer, Neurosci. Lett., 2008, 438, 200.

177 E. Nikulina, J. L. Tidwell, H. N. Dai, B. S. Bregman and M. T. Filbin, Proc. Natl. Acad. Sci. U. S. A., 2004, 101(23), 8786.

178 Y. Zhu, A. Wang, W. Shen, S. Patel, R. Zhang, W. Young and S. Li, Adv. Funct. Mater., 2010, 20(9), 1433.

179 G. H. Kim, D. Halder, J. Park, W. Namkung and I. Shin, Angew. Chem., Int. Ed. Engl., 2014, 53(35), 9271.

180 C. Li, T. Luo, Z. Zheng, A. R. Murphy, X. Wang and D. L. Kaplan, Acta Biomater., 2015, 11, 222.

181 B. Shah, Pyrintegrin Induced Adipogenesis: Biology, Bioengineering and Therapeutics, Doctoral thesis, Columbia University, USA, 2012.

182 B. S. Shah, M. Chen, T. Suzuki, M. Embree, K. Kong, C. H. Lee, L. He, L. Xiang, J. A. Ahn, S. Ding and J. J. Mao, Sci. Rep., 2017, 7, 36402.

183 L. E. Visscher, M. Cheng, M. Chhaya, M. L. Hintz, J. T. Schantz, P. Tran, O. Ung, C. Wong and D. W. Hutmacher, Tissue Eng., Part B, 2017, 23(3), 281.

184 M. P. Chhaya, F. P. W. Melchels, B. M. Holzapfel, J. G. Baldwin and D. W. Hutmacher, Biomaterials, 2015, $52,551$.

185 M. P. Chhaya, E. R. Balmayor, D. W. Hutmacher and J. T. Schantz, Sci. Rep., 2016, 6, 28030.

186 P. S. Korrapati, K. Karthikeyan, A. Satish, V. R. Krishnaswamy, J. R. Venugopal and S. Ramakrishna, Mater. Sci. Eng., C, 2016, 67, 747.

187 S. Chakraborty, T. Ponrasu, S. Chandel, M. Dixit and V. Muthuvijayan, R. Soc. Open Sci., 2018, 5(5), 172017.

188 V. Kant, A. Gopal, D. Kumar, N. N. Pathak, M. Ram, B. L. Jangir, S. K. Tandan and D. Kumar, J. Surg. Res., 2014, 193(2), 978.

189 M. Alibolandi, M. Mohammadi, S. M. Taghdisi, K. Abnous and M. Ramezani, Int. J. Pharm., 2017, 532(1), 466.

190 X. Li, X. Ye, J. Qi, R. Fan, X. Gao, Y. Wu, L. Zhou, A. Tong and G. Guo, Int. J. Nanomed., 2016, 11, 3993. 
191 M. Ranjbar-Mohammadi, S. Rabbani, S. H. Bahrami, M. T. Joghataei and F. Moayer, Mater. Sci. Eng., C, 2016, 69, 1183.

192 Y. Mo, R. Guo, Y. Zhang, W. Xue, B. Cheng and Y. Zhang, Tissue Eng., Part A, 2017, 23(13-14), 597.

193 M. Saberi-Karimian, N. Katsiki, M. Caraglia, M. Boccellino, M. Majeed and A. Sahebkar, Vascular endothelial growth factor: An important molecular target of curcumin, Crit. Rev. Food Sci. Nutr., 2017, 1-14.

194 D. S. Domingo, M. M. Camouse, A. H. Hsia, M. Matsui, D. Maes, N. L. Ward, K. D. Cooper and E. D. Baron, Int. J. Clin. Exp. Pathol., 2010, 3(7), 705.

195 W. H. Lee, C. Y. Loo, M. Bebawy, F. Luk, R. S. Mason and R. Rohanizadeh, Curr. Neuropharmacol., 2013, 11(4), 338.

196 B. S. Nagoba, N. M. Suryawanshi, B. Wadher and S. Selkar, Wounds, 2015, 27(1), 5.

197 S. C. Gupta, S. Prasad, J. H. Kim, S. Patchva, L. J. Webb, I. K. Priyadarsini and B. B. Aggarwal, Nat. Prod. Rep., 2011, 28, 1937.
198 K. A. Weighaus, S. M. Capitosti, C. R. Anderson, R. J. Price, B. R. Blackman, M. L. Brown and E. A. Botchwey, Tissue Eng., 2006, 12(7), 1903.

199 P. Pillarisetti and K. A. Myers, Eur. J. Med. Chem., 2018, 160, 193.

200 M. Schachter, Fundam. Clin. Pharmacol., 2005, 19(1), 117.

201 A. Moshiri, A. M. Sharifi and A. Oryan, Clin. Exp. Pharmacol. Physiol., 2016, 43(7), 659.

202 S. Braun, U. auf Dem Keller, H. Steiling and S. Werner, Philos. Trans. R. Soc., B, 2004, 359(1445), 1471.

203 T. T. Phan, P. See, S. T. Lee and S. Y. Chan, J. Trauma, 2001, $\mathbf{5 1 ,} 927$.

204 A. Oryan, S. Alidadi, A. Moshiri and A. Bigham-Sadegh, Biofactors, 2014, 40(5), 459.

205 Y. C. Chai, A. Carlier, J. Bolander, S. J. Roberts, L. Geris, J. Schrooten, H. Van Oosterwyck and F. P. Luyten, Acta Biomater., 2012, 8(11), 3876.

206 J. Zhao, S. Ohba, Y. Komiyama, M. Shinkai, U. I. Chung and T. Nagamune, Tissue Eng., Part A, 2009, 16(1), 233.

207 H. P. Ma, L. G. Ming, B. F. Ge, Y. K. Zhai, P. Song, C. J. Xian and K. M. Chen, J. Cell. Biochem., 2011, $112(3), 916$. 